Article

\title{
Framing Film-Induced Tourism into a Sustainable Perspective from Romania, Indonesia and Malaysia
}

\author{
Yong Liu ${ }^{1}$, Wei Lee Chin ${ }^{2}$, Florin Nechita ${ }^{3, *}$, and Adina Nicoleta Candrea ${ }^{4}$ \\ 1 Faculty of Arts and Social Sciences, Design and Creative Industries Programme, Universiti Brunei \\ Darussalam, Bandar Seri Begawan BE 1410, Brunei; yong.liu@ubd.edu.bn \\ 2 Faculty of Arts and Social Sciences, Geography, Environment and Development Programmme, \\ Universiti Brunei Darussalam, Bandar Seri Begawan BE 1410, Brunei; weilee.chin@ubd.edu.bn \\ 3 Faculty of Sociology and Communication, Transilvania University of Brașov, 500036 Brașov, Romania \\ 4 Faculty of Economic Sciences and Business Administration, Transilvania University of Brașov, 500036 Brașov, \\ Romania; adina.candrea@unitbv.ro \\ * Correspondence: florin.nechita@unitbv.ro; Tel.: +40-723-693-843
}

Received: 24 October 2020; Accepted: 25 November 2020; Published: 26 November 2020

\begin{abstract}
This paper is particularly focused on film-induced tourism investigation as well as its cultural promotion and cultural change effect that impact on both the tourist destinations and the tourist demands. The case studies include the famous Transylvania, Romania as well as the two comparative destinations in Southeast Asia namely Bali in Indonesia, and Penang in Malaysia. Although tourism planners have limited control over the content of the films produced in the respective destinations and how the destinations are being portrayed in films, it is reflected in our studies that, the imaginary, visual representations of the destinations, albeit negative or distorted from their original identities, are still useful and viable to promote the tourist destinations. The three discussion cases form up the stratification of multiple stages in terms of implementing film-induced tourism strategies to promote their destinations, spanning from one of the oldest film-induced tourist destinations Transylvania, to an over decade-long film-induced destination Ubud in Bali, to a sprouting film-induced destination George Town in Penang. Such a stratification of three comparable destinations leads to both the vertical and horizontal evaluation of the effectiveness of film-induced tourism strategies. Hence, a methodology of multiple-case study with mixed-methods characterised by a set of differing qualitative research approaches will be adopted to the three distinctive destinations, respectively. Emerging markets require new techniques and strategies of marketing, especially in the unsettled post-COVID-19 era. Findings may be useful to destination managers in planning an effective destination image strategy in order to achieve the most sustainable positive impacts and aligning the films' image of the destination with the desired image and the potential audience reach.
\end{abstract}

Keywords: film-induced tourism; destination image; destination marketing; Dracula tourism; Romania; Bali; Paneng; Southeast Asia; sustainable tourism

\section{Introduction}

The link between tourism and media is a contemporary cultural phenomenon that connects destinations, tourism, media industries and fan cultures [1]. Film-induced tourism is known as one of the sub-category within the travel and leisure industry that is linked to the location(s) of a film or TV series. It may be considered as part of the broader category of popular culture-related tourism [2]. Film and media have gained increasing attention and recognition by various academics as their studies indicate the relationship between film-induced tourism and the influence on tourist arrivals has become apparent [3-6]. Previous studies have suggested that film can support the growth 
of tourist arrivals for a particular destination represented therein [7,8]. Similarly, Gjorgievski and Trpkova study [9] supported the above statement, claiming that an individual desire to visit a particular destination is proved to be affected by attractions shown in films although the destination is not directly promoted. Media can play a significant role as a means of raising awareness of a particular destination as well as its cultural appeals, which can be exposed to millions of audiences. Film as a part of the creative industries form an essential element of sustainable tourism product and strongly affect tourism development [10]. This paper is particularly focused on the impactful relationship between film-induced tourism destinations and the cultural promotion and cultural change effect on both the tourist destinations and the tourist demands. The case studies include the famous Bran Castle (Dracula's Castle) in Transylvania, Romania and the comparative destinations in Southeast Asia such as Bali in Indonesia and Penang in Malaysia. The objectives of this paper are twofold. First, it aims to identify and compare film-induced strategies implemented in the three analysed destinations. Second, it aims to provide an empirical investigation based on our first-handed collected data in George Town-Penang, a film tourist destination still at a nascent stage.

\section{Literature Review}

\subsection{Film-Induced Tourism}

Very few studies and little academic literature consider film-induced tourism as a concept before late 1990s, even if it has demonstrated that films play a vital role in destination marketing and development [11].

According to Schofield [12], film-induced tourism has become increasingly popular as more viewers are fascinated by cinematographic history through an actual visiting experience. Film tourism increases the destinations' cultural value, and they are inextricably linked with one another. Through films, there are a variety of cultural meanings, values, emotions that can be expressed from the location and many ancient heritage sites can also be used to reinforce the culture values portrayed within. In addition, a lot of heritage sites filmed in movies have become famous as these places portray specific meanings through film narrations [13]. Film-induced tourism has been investigated from various perspectives such as visitors' experiences, destination image, travel motivation, future behavioural intentions, destination brand construction, and residents' responses [2]. Among the most important contributions of film-induced tourism, the following should be mentioned: 1 . positive economic impacts; 2 . broadening the base of the visitor market; 3 . higher tourist visitation; 4 . increasing visitor numbers; 5 . stronger destination image and destination brand [14].

As the benefits of film-induced tourism are evident, tourist destinations want to create strong and positive destination images through films, but every destination is advised to fully investigate its tourism resources and take into consideration its characteristics [15].

Without the storyline, the ancient building might not be unique enough to capture audience attention [16]. Previous studies have shown that attractions that are exposed in films are more distinguished and well-known with better destination image [17]. Film induced tourism has convinced viewers to travel to a shooting site based on a variety or combination of factors such as the scenery, the plots, the events, the actors or landscapes [13]. Moreover, strategies such as collaborative campaigns carried out by destination management organisations and the film industry have proved to be an effective promotional strategy for film-induced tourism [18-20]. A lot of tourism destinations in New Zealand, Singapore, and UK are working collaboratively with national or regional film commissions and offering incentives to film crews, in order to attract both international and domestic filmmakers to use their destinations as filming locations.

\subsection{The Sustainability Approach on Film-Induced Tourism}

Most academic literature about film-induced tourism presents the positive effects between films and tourism development and/or destination branding [2,3,8,11,21-25]. 
Pop-cultural place-making requires a balance between local community and commercial interests, regular visitors, and temporary fan travellers [1]. The relation between popular culture (generally) and films (particularly) with destinations is complex as communities struggle with both over-tourism and under-tourism, and this kind of niche tourism could challenge even the identity of a place [22]. Therefore, some authors question the contribution of film-induced tourism to the sustainable development of tourism in many places, as in many cases it attracts larger and larger crowds to places affected by over-tourism [26]. There are vast challenges for destinations in managing pop culture-induced tourism such as managing the demands, destination image and the considerations regarding socio-cultural sustainable tourism development [27]. These challenges are indeed applicable to concern about the strategy of film-induced tourism.

Sustainability implies an ethical management of dilemmas such as finding the right balance between growth generated by tourism and protection of the local values [28]. Ethical considerations and knowledge about sustainable development through tourism should be discussed with Destination Marketing Organizations (DMOs) and other stakeholders in order to balance film production interests to the broader community goals [29]. For being effective in the sustainable development of the destination, film-related products should be coordinated with other destination strengths [30]. The first step in managing a sustainable relation between film-induced tourism development and a local community is awareness of potential negative impacts such as exploitation of the local community and local resources [29]. Then a coordinated effort of film production companies, local DMOs and other stakeholders including the local community may work out a prudent strategy of film-induced tourism for a positive, sustainable development.

As films contribute to destination image formation, Croy [21] underlined the need for planning a strategy of effective destination image in order to achieve the most sustainably positive impact on the potential audience and aligning the filmic imagery of the destination with the desired images for the destination. "Films do not always attract huge amounts of visitors to a filming location, they may even destroy an area's reputation, and in the long run, this can make people not want to visit an area" [31]. In order to align image strategy to the desired audience, the perception of potential visitors must be constantly monitored by DMOs to achieve the desired sustainable outcomes. Taking into account of what is special about a specific place, involving the local communities and tourists into a sustainable development for the communities and regions is also specific for creative tourism [32]. If film-induced tourism may be regarded as a unique form of creative tourism, it can easily add at least two Ss (Stories and Sophistication) to the destination and creative tourism toolkit of the four S's model of Richards [33], the visual part to Senses, but the Sustainability part has to be carefully managed.

Heitmann [34] stressed that coordination with the local community and different stakeholders such as film production companies and tourism operators is important for a more sustainable development of film-induced tourism. Other authors consider that inclusion and participation of local residents in film-induced tourism planning and development process are important [35]. The local communities form up the basis for all the future tourism experiences, thus their support lead to a more sustainable long-term life cycle for film-induced tourism destinations [36]. Therefore, the involvement of different stakeholders should be implemented from the early stage of preproduction in filmmaking, as Lundberg and Lindstrom [29] suggested that creative industry should be approached during their setting/location scouting stage by DMOs. According to Thelen, Kim and Scherer [25], four key complexities need to be taken into consideration when analysing the impacts of film-induced tourism: 1 . stakeholder consultation; 2 . diversity within stakeholder groups; 3 . embedded long-term planning approach; 4. inclusion of all relevant stakeholders. Hence, DMOs, film production companies and other stakeholders should work as a long-term partnership and translate it into concrete actions such as film production houses and tourism companies generously provide publicity of the tourism destination, and screen agencies should badger film production companies for economic spend figures [37]. 


\section{Methodology}

Based on previous studies, Chin and Liu [38] concur that there is no substantiated connection between how the image of a location is represented in a film and the viewers' choice of their tourist destinations after watching the film. For instance, an interviewed tourist in their research shared, "I am a huge fan of horror and I love to watch Thailand horror movies. This does not mean that I will perceive Thailand as a horror destination". Therefore, Chin and Liu claimed that the genre of a film does not resonate with the image of the destination [38] (pp. 45-46). However, destinations are usually concerned about how their imagery is portrayed in a film or a TV series, as the representation of a destination country is closely relevant to, and has impact on, its national identity and state image. Some DMOs realise rather late that they should have leveraged the exposure of their destination worldwide even under a negative portrayal [39]. Dracula tourism is such an exemplar that, according to Light, like many other countries, "Romania is not represented in the way that it would choose but instead in the way that the West chooses" [40] (p. 761). The two comparable cases in Southeast Asia-Bali in Indonesia and Penang in Malaysia, are also represented in a few Western movies, in which the two places' original identities are either distorted as, or replaced by, a fictional and exotic exaggeration of Otherness to a certain extent, respectively, in order to satisfy the consumption taste of the global audience.

Therefore, a common imagination of Otherness from the West cast on the aforementioned tourist destinations becomes a rationale to interlink Transylvania, which is located in Eastern Europe, with Bali and Penang, which are located in two adjacent Southeast Asian countries. Such a comparable predicament of the two regions-Southeast Asia and Eastern Europe-is well elaborated by Mrázek [41] in depicting Eastern European travellers in Southeast Asia during the colonial era: although Eastern European countries were never being colonised, "Eastern European identities and self-determination were dreamed and struggled for in the margins, or under the rule, of great empires, West and East, which were trying to divide the region among themselves (rather like Western European empires did in Southeast Asia)". This particular description draws out the broad context and paves the way for our comparative discussion in paralleling the three tourist destinations, Transylvania in Eastern Europe, Bali and Penang in Southeast Asia, and their differing film-induced strategies to promote themselves, respectively, as a popular tourist destination.

Moreover, there are other common grounds to make the comparative bases for the three aforementioned destinations multifold: firstly, before the three places become film-induced tourism destinations, all of them are already well-known tourism destinations. Secondly, the three places are all portrayed in one or more Western (mostly Hollywood) popular movies, in which their respective original identities are either removed or even replaced by a particular representation as a fictional, distorted, exotic destination of Otherness, in order to appeal to the mainly Western audiences' entertainment demands. Such fictionally portrayed images of the three destinations in the respective movies are not necessarily negative, sometimes even romantic or fascinating; however, they are all somewhat distorted from the authentic identities of the three places in reality. Heitmann noted: "Just as the tourism planners have little influence over what is represented on screen, the local community has to live with the consequences of what image has been portrayed, and to whom the image has been portrayed. Particularly in the case of social dramas or ethical dilemmas featured on film, this can have negative consequences" [34] (p. 39). Heitmann's point leads to the third comparable aspect among the three destinations. Although the local tourism planners and local community do not have much control of their destination imagery represented in film(s), they can still consider some of these represented images of their destination as a tactical advantage and manage properly, albeit differently, to turn such an imposed, fictional imagery into effective promotional strategies to facilitate local tourism development. It is worth noting that the three cases altogether form up a stratification of temporal stages in terms of implementing film-induced tourism strategies to promote the respective destinations, spanning from one of the oldest film-induced tourist destinations Transylvania, to a 
decade-long film-induced destination Ubud in Bali, to a sprouting film-induced destination George Town in Penang.

Because of such a disparity of film-induced tourism strategies implemented in the three destinations, we tend to use different qualitative approaches suitable for the respective destinations and then pull together the findings synthetically derived from the multiple methodological approaches. In particular, for the destinations in Romania and Indonesia, our methods mainly approach textual and data analysis based on the abundant, existing literature published by previous studies and a few public data resources released by the national and regional government agencies in the two countries. This tactic makes our discussion not only benefit from the historical depth and abundance of the relevant research conducted by other authors, but also stresses the coherent commonality of the three destinations while comparing the differences among them pertaining to the effectiveness of implementing film-induced tourism strategies. For George Town in Penang, nonetheless, an empirical field work is adopted as a set of semi-structured and in-depth interviews of an array of tourists, local business stakeholders and film producers were carried out during a two-week field trip to the destination. This qualitative method, along with others, allows us to execute our investigation on this film tourist destination still at a nascent stage based on our first-hand collected data, regardless of the lack of the relevant literature and existing data.

In summary, to carry out such a multi-disciplinary, cross-culture research project, the four authors with different academic backgrounds and expertise in respective research areas adopted multiple qualitative methods to engage a comprehensive and comparative study on film-induced tourism strategies implemented in different geographic areas. Although these strategies are derived from some commonality of the three representative destinations, they are in the different stages in terms of adopting film-induced tourism strategies for tourism development. In particular, Transylvania, Romania has some decades-long film-induced tourism development experience, and Ubud, Indonesia has over a decade of evolvement pertaining to film-induced tourism, while Penang, Malaysia is still an emerging film-induced tourism destination in its infancy stage. Such a development disparity of the three destinations determines different approaches of research methods for the respective destinations. For Transylvania and Ubud, we can rely on the abundant existing literature and references, and rich public data, to achieve our particular research purpose; for Penang, a film-induced tourism destination in a nascent stage, an empirical investigation based on first-hand collected data may be the most efficient and available method to incept and then compare our findings with the other two destinations.

Therefore, the methodology we adopt in this study may be considered a multiple-case study with mixed-methods and triangulation in particular. The three cases in our study construct a perfect stratification of film-induced tourism development in different stages. This approach may be considered a process of convergence, as Guetterman, Molina-Azorin and Fetters argued that different "cuts" of a phenomenon studied with different methods could be equally useful as convergence [42]. Such a convergence also reflects what Denzin defined as the triangulation method-the combination of methodologies in the study of the same phenomenon [43] (pp. 291-307). Denzin outlined the following four types of triangulation: (a) data triangulation (i.e., use of a variety of sources in a study), (b) investigator triangulation (i.e., use of several different researchers), (c) theory triangulation (i.e., use of multiple perspectives and theories to interpret the results of a study), and (d) methodological triangulation (i.e., use of multiple methods to study a research problem). Using a case-study approach, this study can be framed within the triangulation research method. Four researchers with different expertise use multiple theories via multiple perspectives, collect data from a variety of sources by adopting mixed methods, compare and analyse all types of data, finally synthesising the conclusion of three comparable film-induced tourism destinations stratified in three developing stages. 


\section{Results}

\subsection{From Dracula to Hotel Transylvania: Dracula Tourism in Transylvania, Romania}

Transylvania is a region situated in the centre of Romania, currently covering nine counties: Alba, Bistriţa-Năsăud, Braşov, Cluj, Covasna, Harghita, Hunedoara, Mureş and Sibiu. It is dominated by the Carpathian mountain range with its pristine forests and it has an international fame due to vampires, castles and wolves [44]. Transylvania has a huge tourism potential and attracts almost a third of the total number of visitors to Romania. Tourist arrivals have been growing in Transylvania in the last ten years and the most popular Transylvanian counties for visitors in 2019 are Braşov, Cluj and Mureş (see Table 1) [45].

Transilvania (often spelled as Transylvania in English literature) is well-known and branded in both contemporary literature/film studies and tourism studies with its genuine association with Dracula-a fictional character that has been rooted in the Western popular culture for over a century. Although the origins and the subsequent demand for Dracula tourism are rooted in Western popular culture, Hovi claimed: "Dracula tourism in Romania is not just Western fiction and fantasy projected onto Romania. Dracula tourism in Romania is a much more versatile form of cultural tourism that combines fiction, tradition, history and culture. Dracula tourism can in fact be seen as a way to promote Romanian heritage through Western popular fiction" [46] (p. 15). As a historical figure in the 15th century Wallachia (a historical region in Southern Romania), Vlad the Impaler has been involuntarily attached to the fictional vampire Count Dracula in Western culture ever since Bram Stoker's novel Dracula was published in 1897, while the factual connection between the two characters "is wafer thin and vague at best" [46] (pp. 61-62), "yet they are persistent and strong" [47] (p. 84). Miller argued that Bram Stoker had no first-hand experience of the Transylvania region and only depended on others' recounted information to design vampire Dracula's homeland Transylvania in his novel Dracula [48]. Light stated that since then more than 200 films about Count Dracula had been made and hundreds more movies that featured vampires as their subject [40] (p. 750). He further claimed: “ ... since many more people had encountered Stoker's vampire through the medium of film, the Dracula appeal is also an early example of movie-induced tourism" [12] (p. 753). The first full Romanian translation of the novel Dracula was published in November 1990, even though Romania had seen an explosion of Western tourists in search of Dracula and vampires during the 1970s [49]. Candrea et al. noted that although many tour agencies utilised Bram Stoker's Dracula in many ways to offer Dracula tourism, most visual elements adopted in Dracula tourism are "definitely movie-inspired" [47] (p. 84). However, Banyai's study showed that while the majority of Western tourists visit Bran, Romania in search for Count Dracula, most of them leave disappointed because the Bran Castle tour guides only focus on presenting the historical truth, rather than the fictional vampire [50] (p. 20). Vlogs and social media came into the picture as vloggers and tourists shared their live experiences, trying to be catchy and authentic, when they combined myth with history, mixed information with emotions and feelings [51].

As a matter of fact, after crowds of tourists from all over the world flock into the famous Bran Castle (see Figure 1) — the so dubbed Dracula's Castle in Transylvania, they can only find detailed introductions of the Transylvanian local culture and regional history, and some of the famous/infamous residents that once lived in the Castle, including a small section particularly for Vlad the Impaler. Surprisingly, if not disappointingly, there is hardly a single trace of the most anticipated vampire Count Dracula throughout the visual and textual displays inside the Castle.

Based on the researchers' observation, most tourists who visit the Castle do not seem too bothered by the "huge" absence of the fictional cultural icon rooted in the Western myth. This is because they can still experience and imagine the various lives and stories of the real people who have resided in the Castle generation by generation, digesting the rich historical activities and local cultures radiated from those true narratives. Meanwhile, Light noted that for those visitors who would like to be immersed in the Dracula myth, "a thriving market in souvenirs with vampire and horror themes developed around Bran Castle" [40] (p. 758). 
Table 1. Tourist arrivals in Transylvania 2009-2019.

\begin{tabular}{|c|c|c|c|c|c|c|c|c|c|c|c|}
\hline Counties in Transylvania/Year & 2009 & 2010 & 2011 & 2012 & 2013 & 2014 & 2015 & 2016 & 2017 & 2018 & 2019 \\
\hline Alba & 44,271 & 47,838 & 78,496 & 95,918 & 101,869 & 107,271 & 154,210 & 167,970 & 172,340 & 194,818 & 201,840 \\
\hline Bistrita-Nasaud & 51,972 & 52,934 & 57,774 & 66,185 & 66,335 & 70,930 & 80,293 & 94,275 & 113,378 & 117,982 & 118,112 \\
\hline Brasov & 451,683 & 510,196 & 642,829 & 737,810 & 834,979 & 865,689 & 997,601 & $1,114,395$ & $1,260,742$ & $1,380,277$ & $1,421,901$ \\
\hline Cluj & 267,625 & 242,374 & 287,083 & 299,233 & 344,629 & 354,820 & 428,812 & 498,465 & 633,569 & 656,508 & 670,560 \\
\hline Covasna & 62,406 & 60,937 & 91,365 & 79,135 & 83,468 & 89,236 & 88,800 & 99,117 & 108,114 & 119,372 & 137,442 \\
\hline Harghita & 69,405 & 76,871 & 100,276 & 103,398 & 114,717 & 124,224 & 157,659 & 183,725 & 205,537 & 220,954 & 237,386 \\
\hline Hunedoara & 81,585 & 71,996 & 82,023 & 86,540 & 88,306 & 110,536 & 151,060 & 143,870 & 168,346 & 189,526 & 194,245 \\
\hline Mures & 200,312 & 202,850 & 259,121 & 353,459 & 394,834 & 410,904 & 495,481 & 517,111 & 544,479 & 571,454 & 599,036 \\
\hline Sibiu & 244,708 & 228,195 & 263,684 & 285,136 & 329,986 & 355,698 & 438,611 & 503,620 & 565,346 & 566,705 & 575,545 \\
\hline Total & $1,473,967$ & 1,494,191 & $1,862,651$ & $2,106,814$ & $2,359,123$ & $2,489,308$ & $2,992,527$ & $3,322,548$ & $3,771,851$ & $4,017,596$ & $4,156,067$ \\
\hline $\begin{array}{l}\text { Share of total tourist } \\
\text { arrivals in Romania }\end{array}$ & $24 \%$ & $25.00 \%$ & $27.00 \%$ & $28.00 \%$ & $30.00 \%$ & $30.00 \%$ & $30.00 \%$ & $31.00 \%$ & $31.00 \%$ & $31.00 \%$ & $31.00 \%$ \\
\hline
\end{tabular}

Source: Romanian National Institute of Statistics. www.insse.ro. 


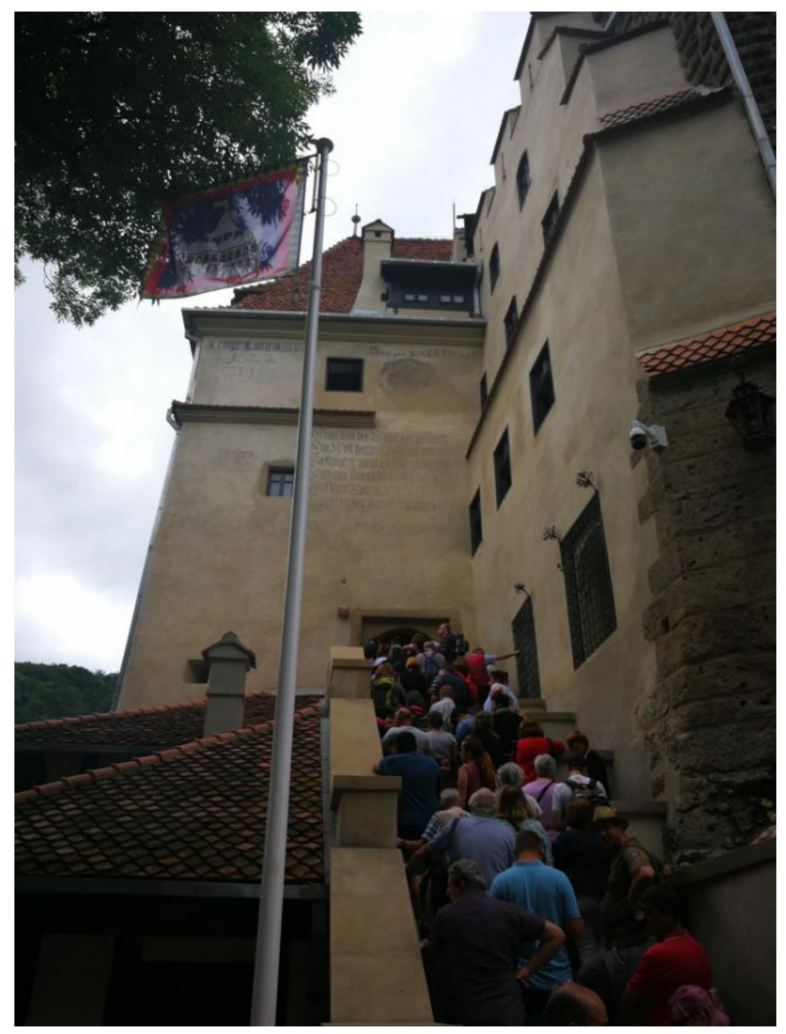

Figure 1. Tourists flock into the famous Bran Castle (also known as Dracula's Castle).

Furthermore, the well-known, fictional Hotel Transylvania in reality is just a 3-star historical hotel (see Figure 2) located in the city centre of Cluj-Napoca, which is regarded as the unofficial capital of the historical Transylvania region; however, from inside out, both the decoration and the architecture of Hotel Transilvania hardly make guests connect it to the Hotel Transylvania movie franchise except for the hotel name itself. Because of its name, Hotel Transilvania was appointed as one of the official accommodation sites for the annual Transilvania International Film Festival (TIFF) for years. TIFF has become the most important film festival in Romania, promoting both Romanian culture through premiering a large number of domestic films and international cultures by screening up-to-date, award-winning foreign movies.

In line with the purpose of local/regional culture promotion, the main dishes served in Hotel Transilvania are mostly Romanian traditional meals including Sarmale, Mămăligăa, and Mici, while the breakfast serves an international or continental buffet. The film festival tour is one of the branches under the film-induced tourism umbrella, its cultural value is very high and culture appeals for tourists are varying from year to year. In 2007, TIFF intentionally used the iconic character Count Dracula as its promotional inspiration along with a mascot resembling Count Orlok (see Figure 3), who was a filmic variation of Count Dracula and originated from the 1922 classic silent film Nosferatu directed by German filmmaker F.W. Murnau [52].

The reason for why after six years from its foundation (2002), TIFF just decided to use the Count Dracula character to promote the festival may be as Light asserted, "Dracula tourism can be identified as a site of struggle between the West's assertion of Romania as Other and the country's efforts to define itself in its own way and on its own terms" [40] (p. 761). In July 2002, the location of building a Dracula Park in Sighișoara-a historical city about $155 \mathrm{~km}$ away from Cluj-Napoca and its medieval citadel is included on the UNESCO World Heritage List-was quietly dropped. In 2005, the controversial Dracula Park project was finally abandoned [40] (p. 759). This was a setback for the Romanian government's first serious attempt to use the Dracula myth for its own tourism promotional purpose after decades of resistance, and then years of reluctance, to endorsing this Western visual trope enforced upon the 
country. This Dracula Park setback may give a plausible explanation why TIFF had not adopted Dracula imagery as its promotional design within the initial several years. However, this temporal setback did not hinder the Romanian government and scholars to continue evaluating the promotional value of both Dracula and Transilvania as alluring attractions for its national tourism strategy. In 2007, the Romanian Master Plan for the Development of National Tourism 2007-2026 mentioned Dracula as one of the country's strengths as a tourist destination, together with Transylvania, in both the cultural section and the marketing and promotion section of the document as a Romanian tourism brand [47]. The year of 2007 was exactly the TIFF first time adopted the character Count Orlok (a variation of Count Dracula) as its promotional emblem.

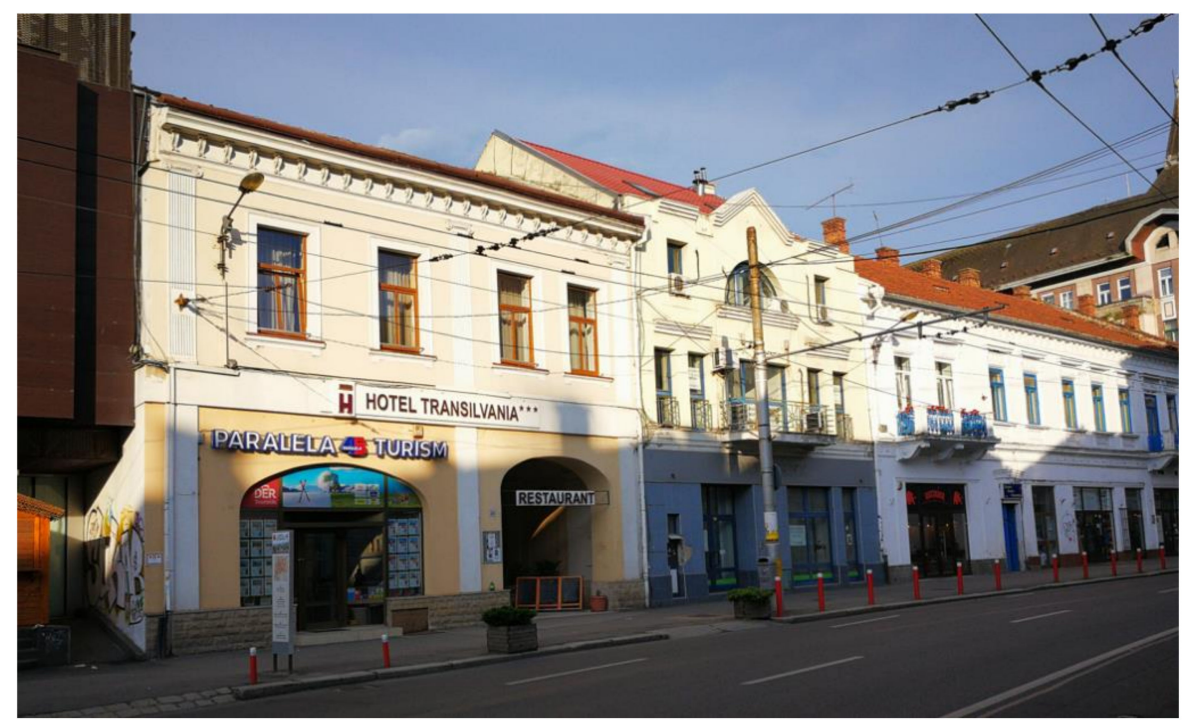

Figure 2. Hotel Transilvania is a 3-star hotel located in the city centre of Cluj-Napoca, Romania.

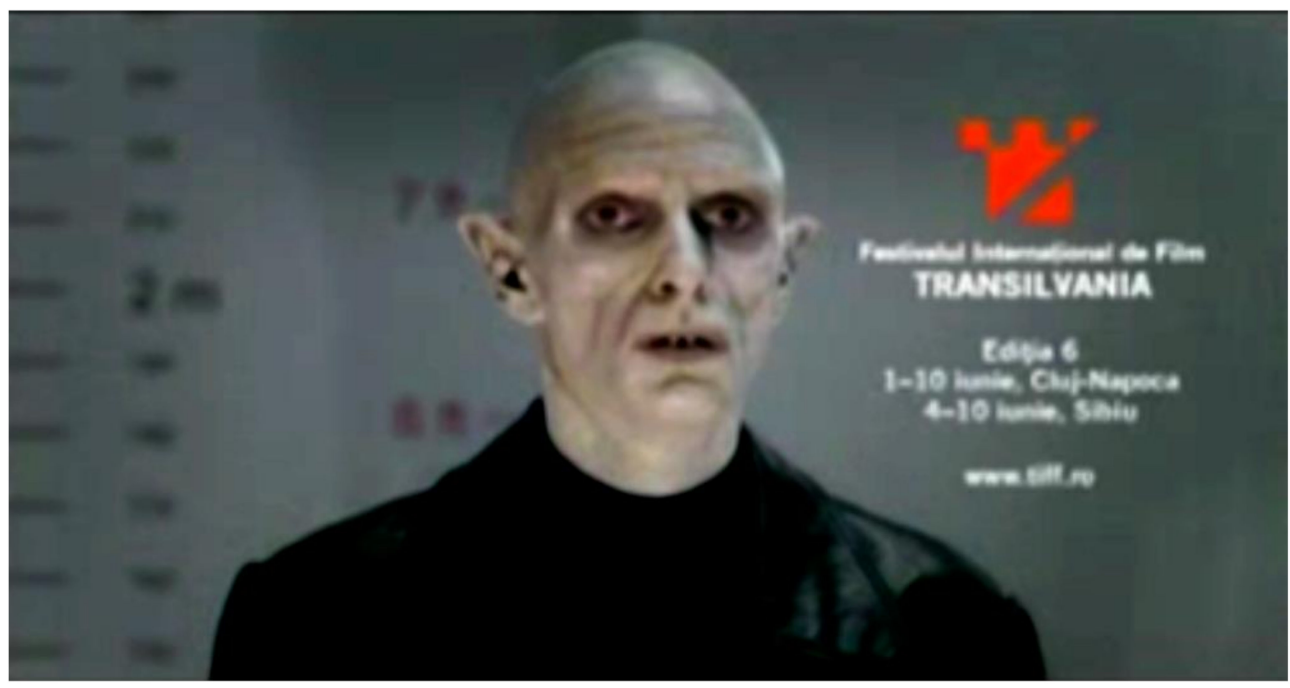

Figure 3. Screen Shot of Count Orlok in advertising for the Transilvania International Film Festival (TIFF) 2007.

The official position of Romanian tourism is rather reluctant to use Dracula as a key ingredient in marketing both Romania and Transylvania as macro-destinations. A simple search through The Operational and Strategic Plan for Romania 2011-2015 provides the insight that Dracula is mentioned as an attribute of Transylvania and "Meeting with the Dracula" as a potential experience [44]. This report quantitatively mentioned Dracula five times and Dracul (Vlad Dracul is a historical figure and the father of Vlad Tepes) two times, whereas biserici (churches) was mentioned twenty-two times, mănăstiri 
(monasteries) six times. As Romania is a country, in which the majority of its citizens declare themselves as Orthodox Christians and the Romanian Orthodox Churches have strong ties with Romanian politics, it can be easy to infer that Romanian official position to Dracula tourism is rather ambiguous.

The national government and local authorities, however, have responsibility to draw up strategic plans through specific public policies for the tourism sector [53], so the difference between the projected image and the perceived image of Romania as a tourist destination can be seen as one of these strategies [54]. This strategy is conspicuously effective when it comes to the reality that local leisure and hospitality businesses persistently and pervasively adopt Dracula or Dracula/Vlad related names to promote their commercial premises (see Tables 2-5), in part contributing to the increasing rate of tourist visitation to Transylvania over the years $[55,56]$.

Table 2. Accommodation units' use of Dracula/Vlad-related names.

\begin{tabular}{|c|c|c|}
\hline Type & Name & City/Town/Village \\
\hline Hostel & Dracula & Arefu \\
\hline Guest house & Dracula & Arefu \\
\hline Camping & Dracula & Arefu \\
\hline Hotel & La Contele Dracula & Vadu Crișului \\
\hline Hotel & Castel Dracula & Tiha Bârgăului \\
\hline Hotel & Acasă la Dracula & Poiana Brașov \\
\hline Guest house & Hanul Dracula & Fundata \\
\hline Guest house & Dracula & Doicesti \\
\hline Hotel & Dracula & Târgoviște \\
\hline Guest house & Hanul Dracula & Daneș \\
\hline Guest house & Dracula & Daneș \\
\hline Guest house & Voievod Dracula & Sighișoara \\
\hline Motel & Dracula & Șelimbăr \\
\hline Guest house & Dracula 2 & Arefu \\
\hline Rented rooms & Vlad & Arefu \\
\hline Guest house & Vlădut & Bran-Predelut \\
\hline Guest house & Contele Vladimir & Sohodol \\
\hline Guest house & Casa Tepeș & Brașov \\
\hline Hotel-apartment & Vlad Țepeș & Brașov \\
\hline Hostel & Casa Vlad & Sighișoara \\
\hline Pension & Prințul Vlad & Săliște \\
\hline
\end{tabular}

Source: Matei (2020), Romanian Ministry of Economy, Energy and Business Environment http://turism.gov.ro/web/ autorizare-turism/.

In recent years, more and more scholars realised that Dracula tourists were a complex mix of multiple interest groups e.g., literary tourists, film tourists, as well as tourists interested in searching for the supernatural roots of Dracula myth or the historical figure of Vlad the Impaler [40,46,47]. A map depicting places linked with both Stoker's Dracula (red) and historical figure Vlad (blue) is presented in Figure 4. Galati, the place mentioned in Stoker's novel and where the return trip of the fictional Dracula to his castle started is not shown on the map as well as the Siret or Prut rivers (mentioned only as a river in the novel). Medias (Mediasch in the novel) is shown with blue on the map as it is a place where real Vlad was imprisoned, but there are no wineries and Golden Mediasch white wine is mentioned in the novel. 
Table 3. Food and beverage services' use of Dracula/Vlad related names.

\begin{tabular}{ccc}
\hline Type & Name & City/Town/Village \\
\hline Bar & Vampire & Sohodol \\
\hline Classic restaurant & Dracula & Căpătătenenii Ungureni \\
\hline Bar & La contele Dracula & Vadul Crișului \\
\hline Classic restaurant & La contele Dracula & Piatra Fântânele \\
\hline Bar & Castel Dracula & Piatra Fântânele \\
\hline Classic restaurant & Castel Dracula & Piatra Fântânele \\
\hline Brasserie & Castel Dracula & Piatra Fântânele \\
\hline Bar & Dracula & Piatra Fântânele \\
\hline Wine cellar & Dracula & Piatra Fântânele \\
\hline Classic restaurant & Acasă la Dracula & Poiana Brașov \\
\hline Bar & Acasă la Dracula & Poiana Brașov \\
\hline Restaurant and Guest house & Dracula & Doicești \\
\hline Classic restaurant & Dracula & Târgoviște \\
\hline Bar & Dracula & Târgoviște \\
\hline Classic restaurant & Dracula & Daneș \\
\hline Classic restaurant & Hanul Dracula & Daneș \\
\hline Classic restaurant & Club Dracula & Sovata \\
\hline Classic restaurant & Dracula & Selimbar
\end{tabular}

Source: Matei (2020), Romanian Ministry of Economy, Energy and Business Environment http://turism.gov.ro/web/ autorizare-turism/.

Table 4. Travel Agencies' use of Dracula-related names.

\begin{tabular}{cccc}
\hline Name & City & Type & Website \\
\hline Beyond Dracula & Bucharest & Online agency & www.beyonddracula.com \\
\hline Beyond Dracula & Timișoara & Online agency & www.beyonddracula.com \\
\hline Dracula Travel & Bucharest & Intermediary & \\
\hline The land of Dracula & Brașov & Organiser agency & www.thelandofdracula.com \\
\hline $\begin{array}{c}\text { Transylvania live-Dracula tours } \\
\text { and Halloween in Transylvania }\end{array}$ & Turda & Online agency & www.visit-transylvania.us
\end{tabular}

Source: Matei (2020), Romanian Ministry of Economy, Energy and Business Environment http://turism.gov.ro/web/ autorizare-turism/.

Table 5. Events' use of Dracula-related names in the Transylvania Region.

\begin{tabular}{|c|c|c|c|}
\hline Name & City/Town & Organiser & Website \\
\hline Dracula Film Festival & Brașov & Fanzin Cultural Association & http://draculafilm.ro/stiri/ \\
\hline Dracula Congress & Brașov & Transylvania University of Brașov & $\begin{array}{c}\text { https://newsbv.ro/2018/10/13/univeristatea- } \\
\text { trasnilvania-organizeaza-dracula-congress-la- } \\
\text { brasov/ }\end{array}$ \\
\hline Dracula in Love Party & Bran & $\begin{array}{l}\text { Casa de Ceai Regina Maria } \\
\text { restaurant inside Bran Castle }\end{array}$ & $\begin{array}{l}\text { http://casadeceai.bran-castle.com/ro/eventsm-2/ } \\
\text { 29-romana/evenimente/54-the-event-dracula-in- } \\
\text { love-party }\end{array}$ \\
\hline $\begin{array}{l}\text { Dracula Halloween } \\
\text { Festival }\end{array}$ & Bran & Bran Castle & $\begin{array}{l}\text { https://bilete.castelulbran.ro/en/petrecere- } \\
\text { halloween-2019.html }\end{array}$ \\
\hline Dracula Horse Festival & Daneș & Dracula Daneș Domain & https://draculahorse.ro \\
\hline Dracula Dog Show & Târgu Mureș & Mureș County Dog Association & https://www.draculadogshow.eu/index.php/en/ \\
\hline $\begin{array}{l}\text { Tracking Dracula Hard } \\
\text { Enduro Race }\end{array}$ & Tihuța area & $\begin{array}{c}\text { Enduro Club Bistrita Sports } \\
\text { Association }\end{array}$ & https://trackingdracula.ro/en/ \\
\hline
\end{tabular}

Source: Matei (2020). 


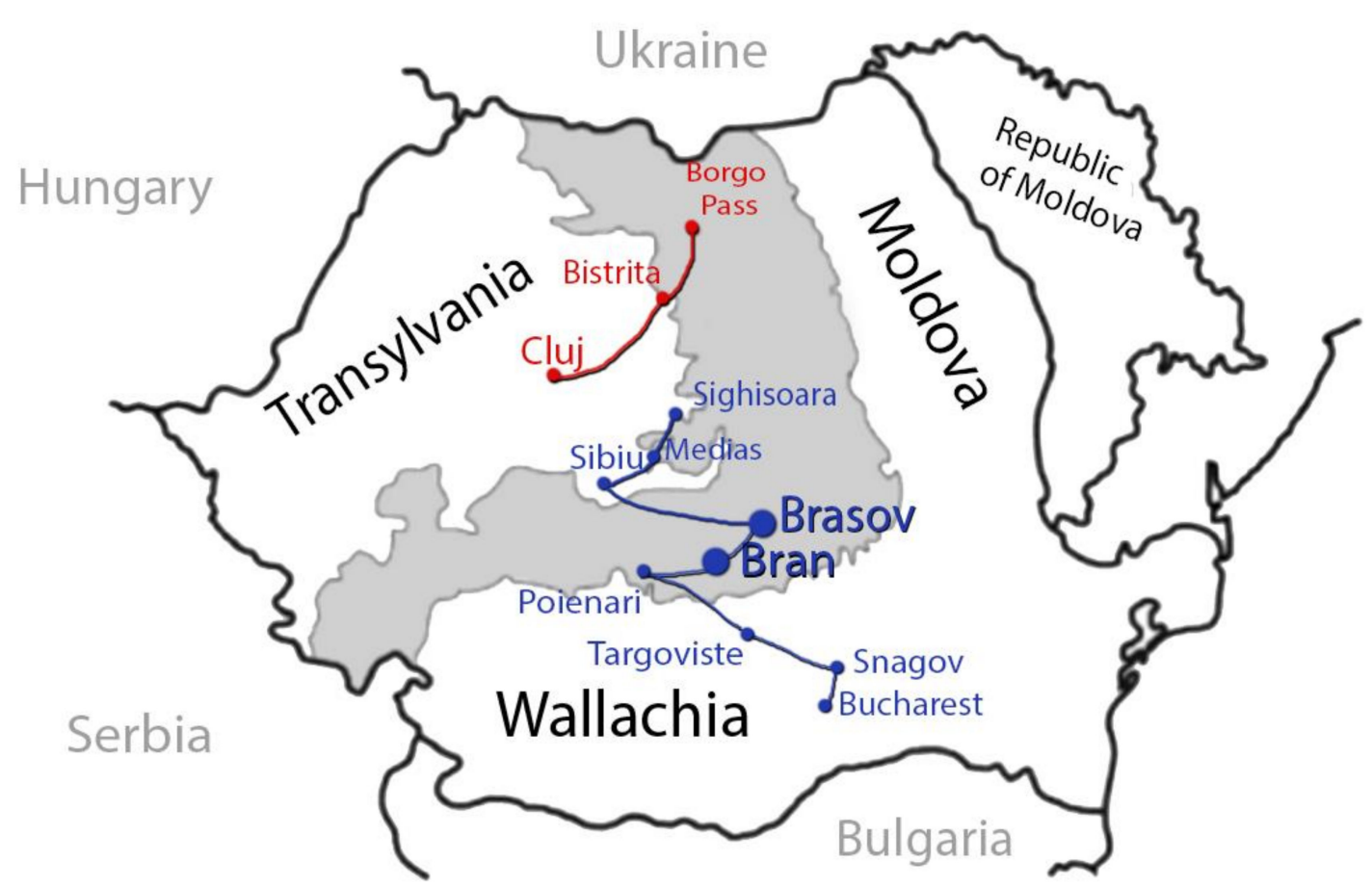

Figure 4. Romanian places related with Stoker's Dracula (red) and Vlad the Impaler (blue).

Therefore, Candrea et al., 2016, suggested that, based on the confirmed popularity of the Dracula myth in Transylvania and its link with the country's stereotyped, negative image, Romania should deal with the Dracula myth wisely and use it as a competitive advantage for promotional purposes strategically [47] (p. 87-88). It is very important to coordinate different tourism activities and guiding visitors to improve their overall experience [57]. The recently founded Dracula Film Festival (see Figure 5) is one example of such a promotional strategy. During the opening ceremony for the Festival's 2019 edition, the organiser screened a pre-recorded congratulatory video from Bram Stocker's grand, grandson in the UK before the opening movie screening. A festival sub-programme-Dracula Digital aims to attract young university students from all over the world to come to Brassov and team up with each other making short horror films with mobile phone cameras. In addition, Dracula Digital provides a precious opportunity for the participating student filmmakers from around the world to experience the diverse Transylvania local cultures and history to achieve their own creative demands.

The increased diversification of Dracula tourists coming to Transylvania may be indebted to the long term persistent promotion of the region's rich historical tradition and cultural heritage, and the constant, resourceful impact on the tourists' renewed expectation and demand change towards the destination over the years. The Dracula myth as a promotional device can be seen to attract more and more tourists from around the globe to Transylvania. However, as tourists from more diverse backgrounds come to visit Transylvania, they maybe carry more diversified touristic interests other than the traditional Western travellers' riveted interest in Dracula tourism. Even Western tourists visiting Transylvania nowadays have differing primary purposes due to Transylvania's tremendous cultural tradition, historical heritage and its diverse natural and recreational resources such as the Carpathian Mountains scenery and the exceptional skiing resorts adorning the Mountains. The various marketing demands in Transylvania, as well as the multiple and specific demands for Dracula tourism, as Candrea et al. suggested, need more statistics as a distinct market segment registered for future meticulous studies about Transylvania tourism [47]. Using the alluring tactic of the Dracula myth to promote the abundant cultural and historical resources in Transylvania appears to be an effective and sustainable film-induced tourism strategy for long term development. 


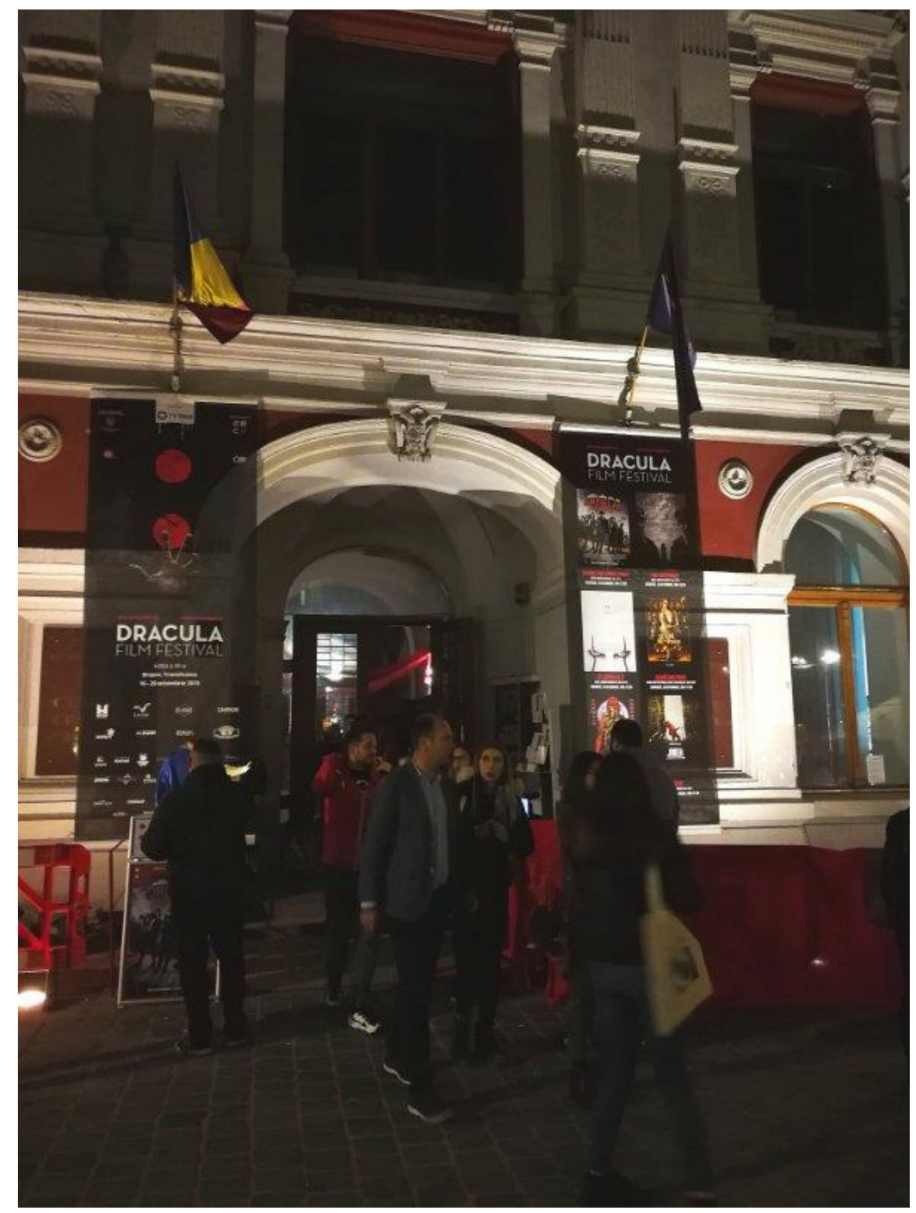

Figure 5. Opening night of the Dracula Film Festival 2019.

Cultural mapping can be an important tool in making the intangible heritage visible as many local resources can bring benefits for the region by involving locals in cooperative actions [32]. In this direction a niche tourism as a form of creative tourism could link the interests of tourists in the Dracula myth with traditions related with rituals of passage or other intangible heritage related to it.

\subsection{From Negeri Laskar Pelangi to Eat Pray Love: Ubud in Bali, Indonesia}

The studies of film-induced tourism in Indonesia have mainly focused on two cases so far: a Hollywood Romantic Drama Eat Pray Love (2010) starring Julia Roberts and its contribution to the ensuing influx of soul-searching tourists from all over the world to Ubud in Bali following the film's global hit; the other is an Indonesian domestic film Negeri Laskar Pelangi (2008) and its boost of mainly Indonesian domestic tourists flooding into the film's shooting location-Belitung island on the east coast of Sumatra (see Figure 6).

For the latter case, Boronnia gave an elaborated discussion in her Master thesis titled "The Making of Negeri Laskar Pelangi (the Land of Rainbow Troops) Film Tourism as Placemaking in Indonesia" [58]. Furthermore, Imanjaya and Kusumawardhana reported in detail how this domestic box-office hit in Indonesia turned its shooting locations on Belitung island, where there was literally no tourism business on the island before the film's release, into the most primary must-see destination on the island and then the host of some international events [59] (pp. 13-15). In order to catch up with the attention from the eyes of the visitors who had just arrived the island, the municipal government of Belitung even renamed Tanjung Pandan harbour (one of the biggest harbours in the Bangka Belitung Province) Pelabuhan Laskar Pelangi (harbour of Laskar Pelangi), which precisely followed the title of the successful film [59] (p. 14). After a tour of a special package of Negeri Laskar Pelangi filming 
locations was launched online, thousands of local and international tourists flocked into Belitung island to join the package tour, so that the local tour operator decided to bring the popular product to an overseas tourism exhibition, in order to promote it to more international tourists in 2013 [59] (p. 21). Therefore, the Negeri Laskar Pelangi (2008) film tour is a successful exemplar for an Indonesian film attracting primarily domestic film tourists to visit a once little-known island destination. Tourism has become one of the three main priorities that are of particular concern for the Bangka Belitung provincial government to implement in the Regional Development Program 2017-2022 [60] (p. 147). "Efforts to develop the tourism sector in the Bangka Belitung Islands are progressing as seen from the increasing number of tourism facilities, transportation, communication and the increasing number of tourists" [60] (p. 148), especially demonstrated by the increasing number of tourists to the Belitung Island (see Figure 7).

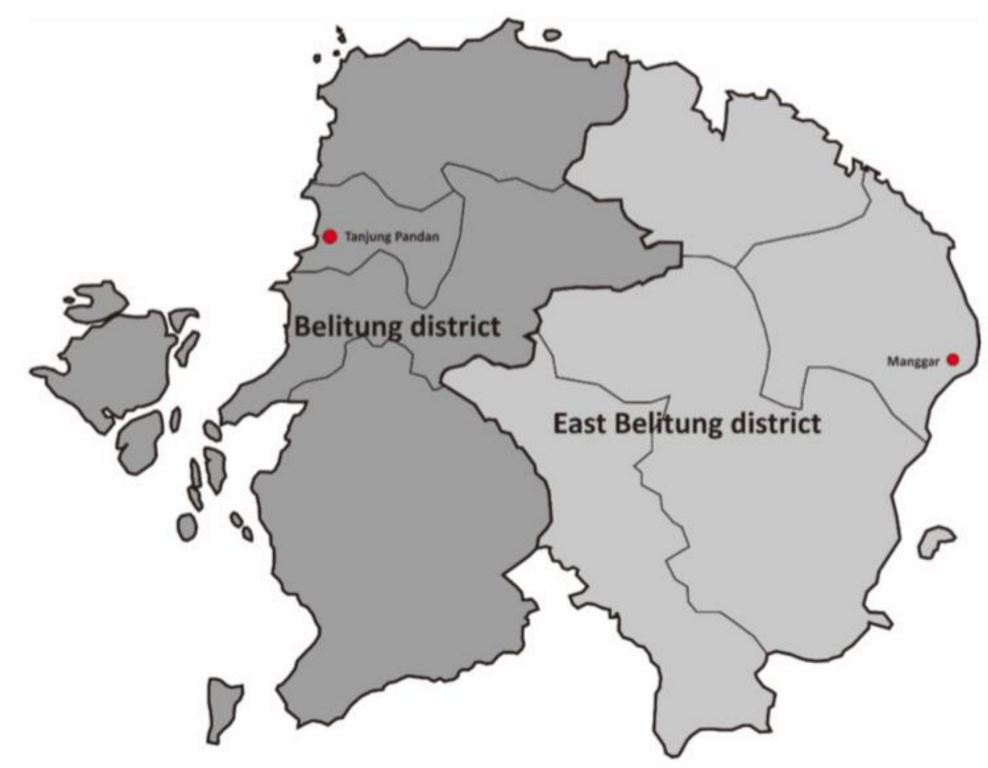

Figure 6. Belitung island, Indonesia.

It is the phenomenon of a sudden influx of an array of niche, special interest tourists to Ubud in Bali following the release of the Hollywood movie Eat Pray Love (2010) that puts one of its main production locations, an already famous tourism destination-Bali under the international spotlight again [61-63]. Our analysis will be focused on the case of Eat Pray Love (EPL, see Figure 8), which induced a mainly international tourist boom to the Ubud district in Bali, Indonesia, in order to compare with other two destinations, namely Transylvania in Romania and Penang in Malaysia. Dubbed as the "Island of Gods and Goddesses", Bali is the most popular tourism destination in Indonesia that attracts millions of international tourists from the globe every year due to its beautiful sceneries and beaches as well as its strong and rich Hindu culture and religious tradition. Hitchcock wrote: "Besides beach-based activities, culture was also seen as a major tourism product building upon Bali's Hindu heritage of temples, dance, and handicrafts" [64]. Ubud, a large village in the centre of the island, has become Bali's cultural and dance "capital", boosting local pride in local Hindu culture, and is used to promote cultural tourism. As EPL's main filming locations, Ubud's status of Bali's cultural and dance "capital" had been long established before the film was released in 2010. As such, both Ubud and the Bali Island have very competitive touristic resources based on its cultural richness and artistic convention. A map of the Ubud district in Bali is presented in Figure 9. 


\section{Number of tourist arrivals in Belitung Island (thousands)}

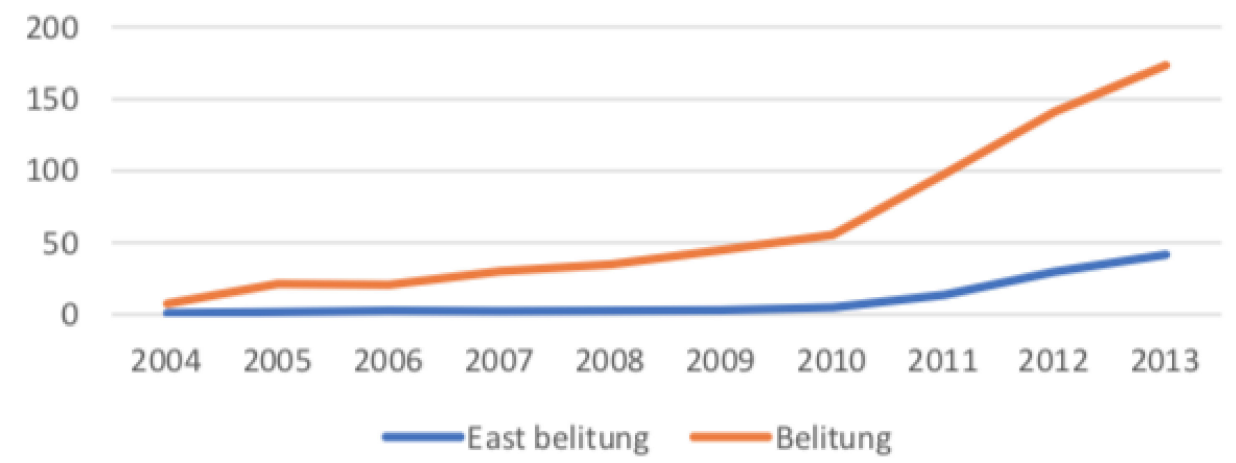

Figure 7. Increasing numbers of tourist arrivals in Belitung Island from 2004 to 2013. Source: Belitung and East Belitung Central Bureau of Statistics (2013).

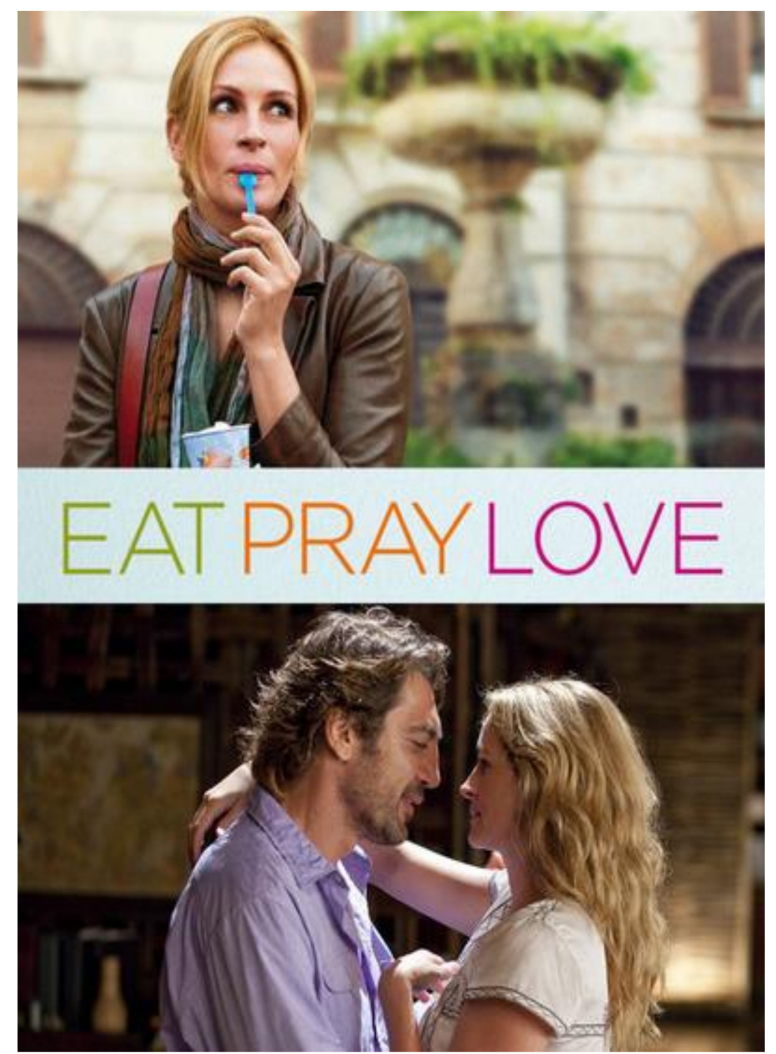

Figure 8. Poster of Eat Pray Love (2010, Dir. Ryan Murphy).

Locals enjoy sharing their everyday life with tourists and appreciate that "guests come here to learn about our tradition and our culture" [65]. Using Kim and Wicks' tourism cluster development model [66], Chin et al. [67] findings substantiated the validity of Porter's National Diamond Model [68] applied to Bali, where the four conditions (core resources, demand conditions, complementary conditions, and destination management) have proven to be important factors for destination competitiveness. Bali was regarded as successful as the four factor conditions were an added advantage in its global tourism competitiveness [67]. 


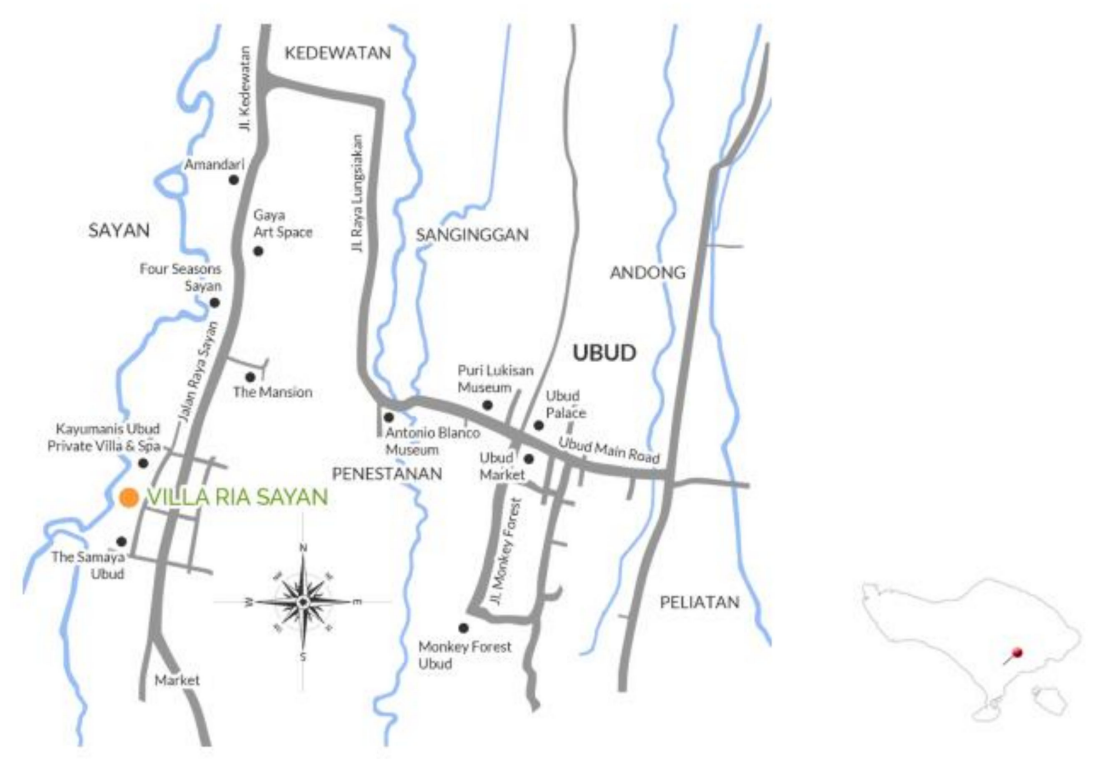

Figure 9. Ubud District in Bali, Indonesia.

In fact, EPL's global box-office success in 2010 only resulted in the influx of a niche, special interest group of tourists to Ubud in Bali, but the effect lasted for years. "Since then, both local and international tourism businesses have attempted to capitalise on the significance and popularity of the new EPL tourism patterns and trends by developing and offering a variety of tour and accommodation packages tailored to include the main EPL experiences portrayed in the film" [69]. Park further observed that women travelling, either alone or with friends, were encountered more often in Ubud than other parts of Bali, and many of them were looking for the local markets and villa where Julia Roberts' character had visited and lived in the film [69] (p. 112). As boasted on Indonesia's official tourism website: "Not even Italy or India could give her the peace she longed for ... And she found it in Bali, island of gods and goddesses" [61]. Then the website offers a tour package included a chain of sites to visit. "Tourists' experiences of Ubud in Bali have been evolving from conventional cultural tourism to more complex or indeed hybrid type of cultural experiences" [69].

Moreover, Imanjaya and Kusumawardhana noted: "Interestingly, the tour package underlines Bali as a spiritual tourist destination [59]. For example, STA Travel put a tagline on its website with the sentence: "Embrace romance in paradise with an experience in Bali taken straight from the movie Eat Pray Love." followed by daily itinerary with no direct relation with the movie or the novel". Promoting Ubud and Bali "as a spiritual tourist destination" is a tangible and tactical strategy, because it is derived and has benefited from the long history of Bali's Hindu religious and cultural tradition and Ubud as the cultural and dance "capital" in Bali. Although, this promoted spiritual tourist destination is quite remote from the romanticised, fictitious Ubud featured in the film $E P L$, hence there is a disparity between the expectation of the EPL tourists, who are particularly interested in experiencing what Julia Roberts' character experienced in the film, and the itinerary of the tour package for sighting a real Ubud, the strategy may pay off in the long term. Not only does this strategy rely on exploiting the rich cultural resources and the historical heritage of Bali, thereby being sustainable for the destination's long term development, it is also effective to prompt local tour operators to explore more innovative products revolving around the local cultural tradition to satisfy tourists' more and more diversified demands (see Figure 10). Here, the Indonesian official tourism website's strategy that utilises the romanticised, imaginary Ubud destination represented in the film EPL to consolidate Bali's tourism competitiveness based on its cultural distinction and abundance is similar to the Bran Castle's promotion tactic - using Dracula the myth to promote Transylvania's abundant historical and cultural traditions. Such a use-it-for-my-purpose sort of strategy, again, accentuates the importance of 
co-operation between government policymakers/planners, DMOs, and local communities, boosting the most sustainable model for film-induced tourism development.

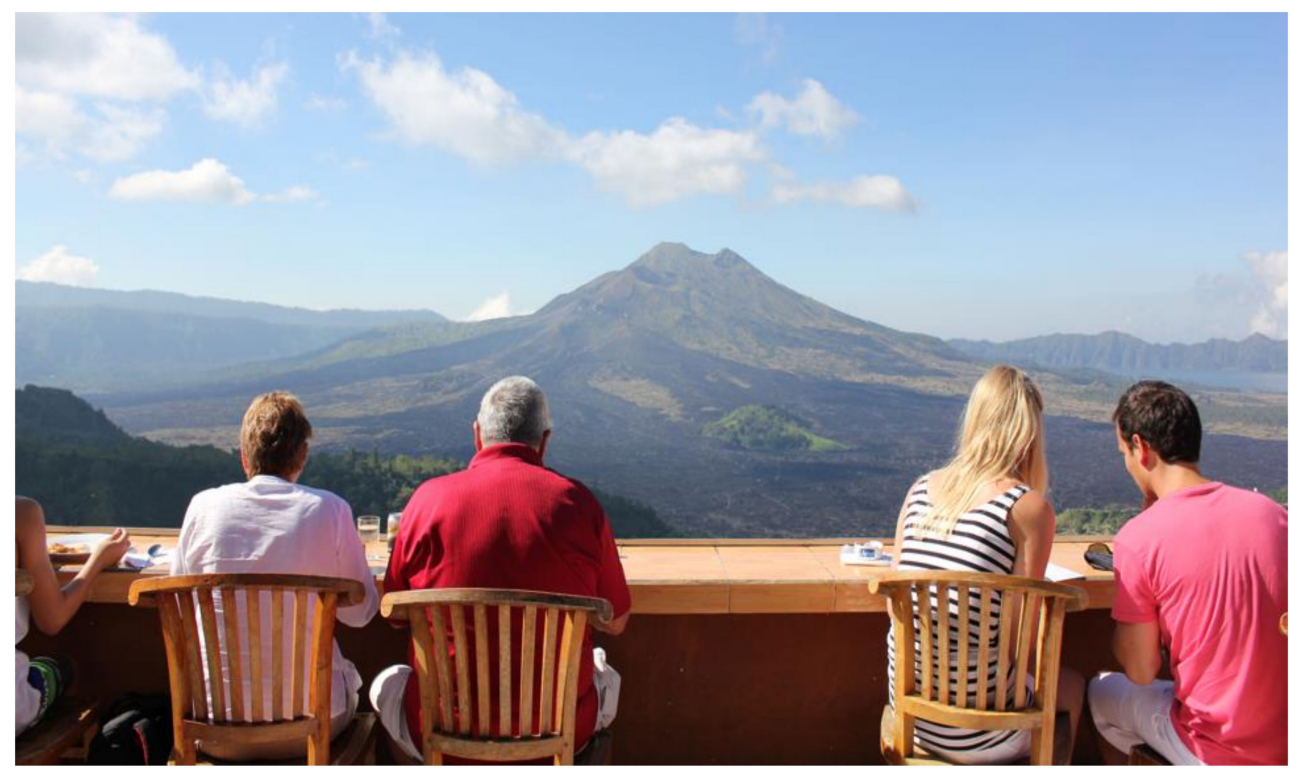

Figure 10. Spectacular view of Mount Batur from Kintamani in Bali.

\subsection{From Indochine to Crazy Rich Asians: George Town in Penang, Malaysia}

Malaysia's tourism development has been experiencing a fast growth and the rich blend of cultural and heritage tourism has contributed to attract tourists from around the globe. Cultural and heritage tourism in Malaysia has been promoted vigorously due to its difference in ethnicity present in Malaysia. This diversity in culture has emerged as a potential for alternative tourism and has brought a diversity in local knowledge with a blend of Malay, Chinese and Indian architectures, handicrafts, music and dance, which brand Malaysia as a colourful, integrated culture unison. With this ethnical and cultural diversity, Malaysia has become a popular spot for filming locations for an array of Hollywood blockbuster movies as well as regional and domestic films. Film companies, mostly from Western countries, more often shoot a scene in Malaysia to simulate a place in another country in their films. Such a production modal could trace back to the Oscar-winning French film Indochine (1992). The most recent example is the 2018 Hollywood hit Crazy Rich Asians; a large number of scenes in it were filmed in Malaysia such as the Kuala Lumpur Carcosa Sri Negara, which was used as an exterior shot for the Young family home in Singapore; Langkawi Island was used as a backdrop for the bachelor party scene, while Cheong Fatt Tze mansion in George Town, Penang was filmed for an iconic courtyard mahjong scene, which brings out the blended culture of Southeast Asia [70].

A number of filmmakers from Hollywood and other countries have chosen to shoot in Penang, a small island located at the Malacca Strait, off the north-western coast of Peninsular Malaysia, due to the rare distinction of George Town, its capital city being a UNESCO World Heritage Site (Figure 11).

Penang portrays a blend of Malay, Chinese, Indian, Peranakan and European influences with endless murals, street art and the preservation of traditional and ancient architectures and buildings, all of them playing a combination of significant roles in creating a rich cultural atmosphere. Cheong Fatt Tze mansion (see Figure 12) in George Town, inscribed as UNESCO World Heritage Site, not only recently appeared in Crazy Rich Asians (2018), but was much earlier filmed in the Oscar-winning French film Indochine (1992). However, George Town is not represented as its own destination identity but as an imaginary other place in both films-respectively, Cheong Fatt Tze mansion was used for the Young family home in Singapore in the former, while it was a set in the French Colonial Vietnam during the 1930s-1950s in the latter. 


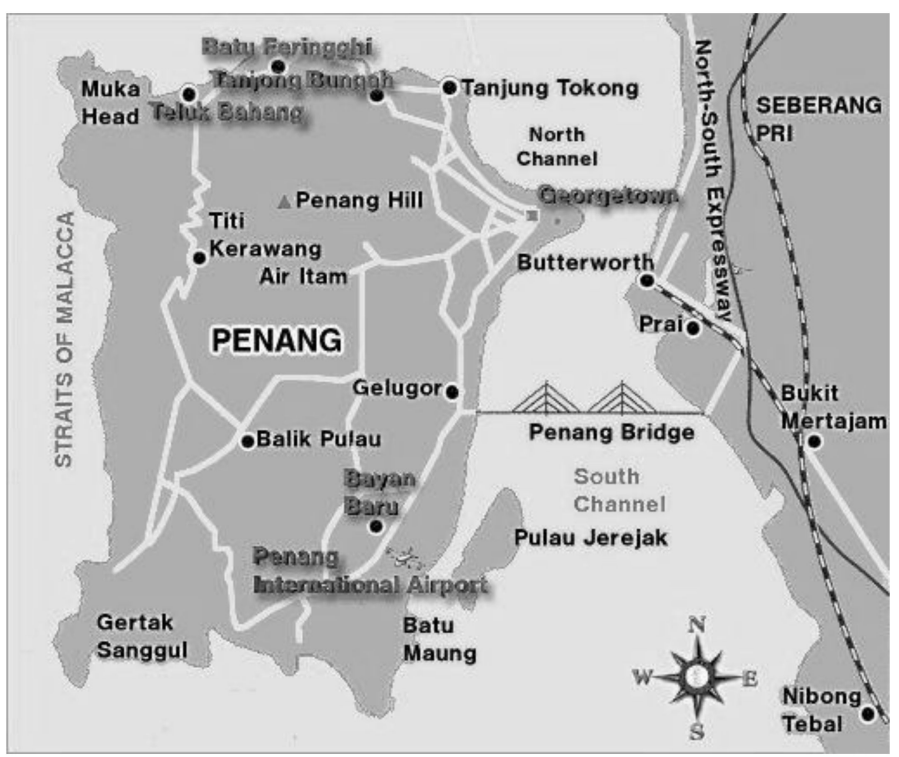

Figure 11. George Town in Penang, Malaysia (source: caingram.info).

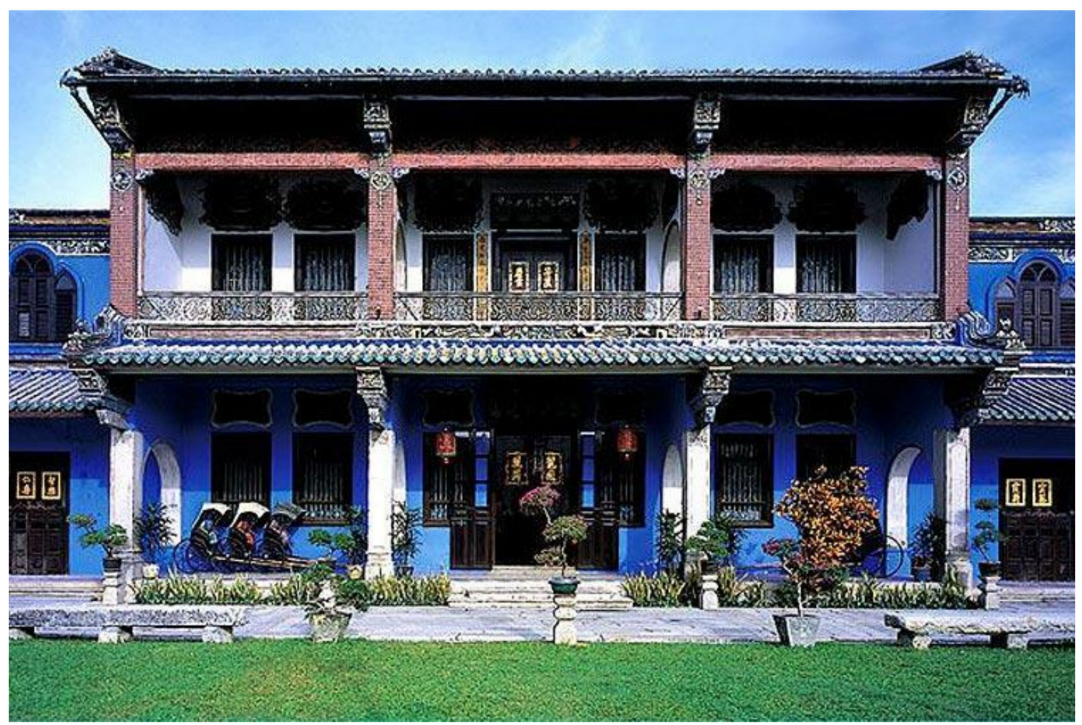

Figure 12. Cheong Fatt Tze mansion in George Town, Penang.

Likewise, in the Hollywood movie Anna and the King (1999), Armenian Street in George Town was converted into the Nineteenth Century Siam (Thailand). In award-winning director Ang Lee's film Lust, Caution (2007), which set the storylines in Hong Kong and Shanghai during the 1930s and 1940s, the one-day shooting in George Town transformed Wisma Yeap Chor Ee into a shopping outlet in the film while the entire road-China Street Ghaut—was closed off [71]. The Eastern \& Oriental Hotel, Penang, which is also located in George Town, was the actual set filmed for the opening scene in Crazy Rich Asians - the fictional Calthorpe Hotel in London, UK [72].

Although there is no tangible evidence that film-induced tourism increases the number of tourist arrivals in George Town, Penang, it is difficult to ignore that filming in a certain location e.g., George Town gives exposure of Penang's cultural and historical distinctions to unlimited audiences. The preferences of tourists have changed, and it is certainly insufficient in today's competitive world to only offer physical infrastructure e.g., temples, beaches, museums or botanic gardens. Infrastructure and attractions are seen as merely a supportive role in appealing to tourists nowadays. Tourists are looking for different cultural experiences and traditions that they are eager to immerse themselves 
into-perhaps the culture values incorporated in the movies that are shot in Penang or the culture activities that they can experience or relate to in those movies.

In order to gather some evidence, 35 respondents with a mixture of different nationalities were queried for a brief interview during a fortnight of field work in George Town, Penang in December 2019 (see Table 6). All of the 27 tourists expressed that they came to Penang to experience the interesting culture and lifestyle offered by its street arts, murals as well as the ancient architectures. Out of the 35 respondents, 18 of them were Western tourists coming from the USA, Canada, UK, Ireland, Sweden, Australia as well as New Zealand. When asked if any film was ever the factor that affected their decision to visit Penang, 14 of them answered "yes" to a certain extent. All of the respondents had seen films with storylines depicting Asian cultures, which had intrigued them all the while to travel here.

Table 6. Profiles of Respondents interviewed in Penang, Malaysia.

\begin{tabular}{|c|c|c|c|c|}
\hline Name & Gender & Country & Tourists/Local Occupations & Interview Duration \\
\hline R1 & $\mathrm{F}$ & USA & Tourist & $10 \mathrm{~min}$ \\
\hline $\mathrm{R} 2$ & M & USA & Tourist & $12 \mathrm{~min}$ \\
\hline $\mathrm{R} 3$ & M & USA & Tourist & $20 \mathrm{~min}$ \\
\hline $\mathrm{R} 4$ & $\mathrm{M}$ & USA & Tourist & $16 \mathrm{~min}$ \\
\hline $\mathrm{R} 5$ & F & Sweden & Tourist & $14 \mathrm{~min}$ \\
\hline R6 & $\mathrm{F}$ & Sweden & Tourist & $12 \mathrm{~min}$ \\
\hline R7 & M & Australia & Tourist & $20 \mathrm{~min}$ \\
\hline R8 & $\mathrm{F}$ & Australia & Tourist & $17 \mathrm{~min}$ \\
\hline R9 & $\mathrm{F}$ & UK & Tourist & $12 \mathrm{~min}$ \\
\hline R10 & $\mathrm{F}$ & UK & Tourist & $14 \mathrm{~min}$ \\
\hline R11 & M & UK & Tourist & $15 \mathrm{~min}$ \\
\hline R12 & M & Ireland & Tourist & $10 \mathrm{~min}$ \\
\hline R13 & M & Ireland & Tourist & $12 \mathrm{~min}$ \\
\hline R14 & $\mathrm{F}$ & Canada & Tourist & $20 \mathrm{~min}$ \\
\hline R15 & $\mathrm{M}$ & Canada & Tourist & $22 \mathrm{~min}$ \\
\hline R16 & F & New Zealand & Tourist & $25 \mathrm{~min}$ \\
\hline R17 & $\mathrm{M}$ & New Zealand & Tourist & $15 \mathrm{~min}$ \\
\hline R18 & M & New Zealand & Tourist & $16 \mathrm{~min}$ \\
\hline R19 & F & Singapore & Tourist & $14 \mathrm{~min}$ \\
\hline $\mathrm{R} 20$ & $\mathrm{~F}$ & Singapore & Tourist & $19 \mathrm{~min}$ \\
\hline $\mathrm{R} 21$ & $\mathrm{M}$ & Singapore & Tourist & $20 \mathrm{~min}$ \\
\hline $\mathrm{R} 22$ & $\mathrm{~F}$ & Thailand & Tourist & $13 \mathrm{~min}$ \\
\hline $\mathrm{R} 23$ & M & Thailand & Tourist & $10 \mathrm{~min}$ \\
\hline $\mathrm{R} 24$ & $\mathrm{M}$ & Thailand & Tourist & $20 \mathrm{~min}$ \\
\hline $\mathrm{R} 25$ & M & Thailand & Tourist & $15 \mathrm{~min}$ \\
\hline $\mathrm{R} 26$ & $\mathrm{~F}$ & Vietnam & Tourist & $12 \mathrm{~min}$ \\
\hline $\mathrm{R} 27$ & M & Vietnam & Tourist & $10 \mathrm{~min}$ \\
\hline R28 & $\mathrm{F}$ & Penang, Malaysia & Café owner & $15 \mathrm{~min}$ \\
\hline R29 & $\mathrm{M}$ & Penang, Malaysia & Tour guide & $20 \mathrm{~min}$ \\
\hline $\mathrm{R} 30$ & $\mathrm{~F}$ & Penang, Malaysia & Tour guide & $19 \mathrm{~min}$ \\
\hline R31 & $\mathrm{M}$ & Penang, Malaysia & Peddler & $14 \mathrm{~min}$ \\
\hline $\mathrm{R} 32$ & M & Penang, Malaysia & Peddler & $15 \mathrm{~min}$ \\
\hline R33 & $\mathrm{F}$ & Penang, Malaysia & Souvenir shopkeeper & $17 \mathrm{~min}$ \\
\hline $\mathrm{R} 34$ & M & Penang, Malaysia & Local Movie Producer & $25 \mathrm{~min}$ \\
\hline R35 & $\mathrm{F}$ & Penang, Malaysia & Local Movie Producer & $27 \mathrm{~min}$ \\
\hline
\end{tabular}

However, most of them said that the urge to visit a particular destination was not immediate or urgent but had a playing factor in influencing them. Respondents 16, 17 and 18 from New Zealand expressed that- 
Movies beside the attractive actors and actresses help remind us the beauty of what other countries have ... my son has watched the movie Crazy Rich Asians multiple times, almost every alternate day on repeat; so we have decided to bring him along to visit Singapore. My son then did his research and read that this movie was partly filmed in Penang; then we decided to also come to Penang and to my surprise, there is even more to see [here] than in the movie.

Respondent 7 replied: "It's not watching one film per se which affected my decision to visit this beautiful country. It is also my self interest in the Asian culture and it undeniably helps that some movies have done such great work in portraying the Asian culture." Although respondent 7 did not mention any title of the movie, his reply does echo the New Zealand respondents 16, 17 and $18^{\prime}$ s emphatic tone on the Asian culture described in movies that they have watched for their travel decision-making.

In addition, 9 other respondents are from Southeast Asian countries, in other words they are more familiar with the blended local culture. When asked if film played an important role in attracting them to a destination, most of them said "yes". Most of them expressed that the storyline of the movie is important as it brings the connection between the movie and real life. Respondents 19, 20 and 21 from Singapore said-

We went to a travel agent near our hotel and they marketed Armenian Street with all the movies being filmed there. I was instantly hooked and joined the tour as I am a big movie fanatic and a lot of local Chinese movies such as The Blue Mansion, Road to Dawn and The Red Kebaya are all shot in Penang. I feel that I was given the chance to walk and visit the place in the movie and transported back to the olden days.

Four of the respondents from Bangkok mentioned they visited Singapore and Penang because of the movie Crazy Rich Asians (2018)_

I want to feel connected to the movie and experience the luxury life portrayed in the movie and experience the Chinese culture. The tour operator from Bangkok told us part of the programme was to go and visit the museum where the popular movie Crazy Rich Asians was being filmed. We were thrilled. (Respondent 24)

The findings show that although the push factor of making tourists visit a particular destination is not immediate, film does help in influencing the decisions of tourists and the continuous reminders of scenes in business marketing strategy help attract tourists to the particular places shown in movies. Although the number of respondents is small and might not have an accurate representation of all the tourists who have visited Penang, it at least provides us a snapshot of how some tourists feel about the link between film and visiting a particular destination.

In addition, six local residents consisting of café owners, peddlers, shop owners and tour guides were also interviewed. All of them were really positive about tourism and expressed that their business has boomed due to the arrival of more tourists. Their quality of life has been hugely improved due to constant profitable businesses. However, most of the local residents have no knowledge on the link between film and tourism except the two tour guides. Moreover, two local movie producers in George Town, Penang were also interviewed. Both of them expressed that the movie scene in Penang has been improving throughout the years and the local government has started recognising the importance of film production and has been really supportive of local producers-

Local government has been encouraging local producers to produce more movies to promote Penang and also encourage us to collaborate with producers outside of Penang. Paperwork and bureaucracy has been lessened and the government has organised events and festivals to showcase local talents and hopefully exposed them to international market. (Respondent 35) 
Indeed, as is stressed in previous sections, to make a film-induced tourism strategy function effectively, it is crucial to build up the co-operative relationship and coordinated implementation between government policymakers/planners, creative talents, and destination managers/agents. The Penang government has decided to actively promote the local film festival to attract both domestic and international tourists in the hope of seeing more local filmmakers portray Penang in its original and authentic state in their films. For example, Penang hosted the second annual SeaShorts Film Festival, which was initiated by the Next New Wave organisation, in George Town in 2018 with the purpose of nurturing young and emerging filmmakers in Malaysia and beyond. This annual collaboration of short film programmes brought filmmakers from all the ten ASEAN (Association of Southeast Asian Nations) member states, namely Thailand, Singapore, Indonesia, Myanmar, Cambodia, Brunei, Malaysia, Philippines, Laos and Vietnam, facilitating the development of filmmaking in the Southeast Asian region as well as promoting Penang as a promising film-induced tourism destination.

With such constant exposure of George Town, Penang to producers and audiences from both Malaysia and outside Malaysia, not only have opportunities been engendered for local filmmakers to present a real imagery of the destination, but tons of tourism promotional opportunities for destination planners and managers have also arisen. The significant change in tourist demand and the importance of film induced tourism are obviously recognised by the Malaysian Inbound Tourism Association (MITA) and Malaysia Tourism Council (MTC), which are the two policymakers for the Malaysia tourism industry.

Unlike Transylvania and Ubud, whose original destination identity has been either distorted by a swath of film and television works related to the well-known Western myth or visually romanticised by a popular Hollywood blockbuster, the real identity of Penang featured in the popular Western movies is a complete displacement by other places that it has been portrayed as in those fictional narratives. For a long time, the majority of the Hollywood and other Western films shot in Penang have portrayed George Town, Penang as a fictional representation for an array of exotic destinations of Otherness, thereby removing the original identities of the destination itself. Although tourism planners have limited control over the content of a film and how the destination is being portrayed, it is reflected in our findings as positive in the case of George Town, Penang when it is used and seen as a successful tactical strategy to promote itself as a tourist destination. When asked about their views on fictional, imaginary representation of George Town, Penang in international movies, both of the local producers do not see it as a big issue: "We are working for exposure at this stage. Any publication or marketing, good or bad, is something [useful]. It gives limelight to Penang" (Respondent 34 and 35). To this day, George Town, Penang has continued to be portrayed as a destination with dynamic and blended cultures, regardless of being portrayed as fictional or realistic in the films. New emerging markets require new techniques of marketing dependent on their intrinsic resources and advantages; therefore, understanding the demand patterns of tourists is tremendously significant in order to ensure what promotional strategies are working, especially when adopting strategies of film-induced tourism to achieve sustainable marketing purposes.

\section{Discussion}

In some cases, film-induced tourism may lead to over-tourism (such as the case of Dubrovnik, in Croatia, following Game of Thrones TV series; Skelling Michael, Ireland, following the movie Star Wars; Maya Bay, Thailand, following the movie The Beach). However, this paper shows that this is not the case of the three analysed destinations, where film-induced tourism is a generator of local development. Moreover, based on the comparative analysis of the three case studies, we may conclude that the less developed destination, Penang, Malaysia may follow the film-induced strategies implemented in the other destinations presented in the article from Transylvania, Romania, to the two destinations in Indonesia.

An interesting result of the comparative analysis between the analysed tourist destinations refers to the Transylvanian tourist destination-Bran, where there is a medieval castle that tourists are associating 
with vampire Dracula's residence. Previous studies have shown that the majority of Western tourists visit Bran, Romania in search for Count Dracula, leave disappointed because the Bran Castle tour guides only focus on presenting the historical truth, rather than the fictional vampire. The Castle is a well-established cultural attraction, with a long history, starting from the 13th century, so it may be quite difficult for its managers and employees to blend the site's real history with fictional information from the film-induced character vampire Dracula. In a similar manner, in the case of Ubud in Bali, although this promoted spiritual tourist destination is quite remote from the romanticized, fictitious Ubud featured in the film EPL, we found that there is a disparity between the expectation of the EPL tourists, who are particularly interested in experiencing what Julia Roberts' character experienced in the film, and the itinerary of the tour package for sighting a real Ubud. The Indonesian official tourism website's strategy that utilises the romanticized, imaginary Ubud destination represented in the film EPL to consolidate Bali's tourism competitiveness based on its cultural distinction and abundance is similar to Bran Castle's promotion tactic - using the Dracula myth to promote Transylvania's abundant historical and cultural traditions. Such a use-it-for-my-purpose sort of strategy, again, accentuates the importance of co-operation between government policymakers/planners, DMOs, and local communities, boosting the most sustainable model for film-induced tourism development.

The stratified selection of the three destinations in our research allows one of our authors approaching conspicuously differing, but still qualitative, methods such as semi-structured interviews of a wide range of targeted groups in Penang, Malaysia, in order to collect empirical evidence for us to make comparison with other two matured film-induced tourism destinations in Romania and Indonesia. As one of the earliest literature and film-induced tourism destinations in the world, Transilvania has been the most discussed and studied in the criteria for decades; Ubud has also gained a prominent reputation of a successful film-induced tourism destination for over a decade. As the youngest in the stratification and a nascent film-induced tourism destination, Penang has been rarely documented in the criterion of film-induced tourism strategies adopted in both public data and the convincing literature. Therefore, our first-hand collected data based on thirty-five in-depth, semi-structured interviews of a wide range of stakeholders such as international tourists, local business owners, tourism operators, and local film producers, plus local news report about governmental facilitation, synthesise a crystallised trajectory of Penang evolving into a promising film-induced tourism destination. Regardless of how fictionally displaced Penang has been portrayed from its original identity in Western movies, just like how fantastically remote Transilvania and Ubud have long been visualised from their respective original identity, the use-it-for-my-purpose sort of film-induced tourism strategies appears both sustainable and promising for a longer term development for the three destinations.

The outcomes of the qualitative research conducted in Penang, Malaysia reveal that although all interviewed visitors chose the destination for its interesting culture and lifestyle, to a certain extent (for half of the interviewed visitors), their choice was also induced by films such as Crazy Rich Asians, The Blue Mansion, Road to Dawn and The Red Kebaya. Local government is already taking measures to promote local film festivals to attract both domestic and international tourists in the hope to see more local filmmakers portray Penang in its original and authentic state in their films. However, it seems that local business owners are not aware of this situation. Although they acknowledge that their business has boomed due to the arrival of more tourists and their quality of life has been hugely improved due to constant profitable businesses, they have no knowledge on the link between film and tourism with the exception of the two tour guide respondents. Therefore, local and national authorities need to inform tourism stakeholders on the benefits that film-induced tourism brings to the destination and assist them in finding the most sustainable ways of taking advantage of this opportunity.

\section{Facing the Challenges of the COVID-19 Pandemic}

Despite the insightful findings of the present study, we cannot ignore the current COVID-19 pandemic, which has completely changed the context of tourism in general, and particularly of 
film-induced tourist destinations, as well as the opportunities for other international destinations to become film locations. Amid the global fight against the COVID-19 pandemic, many thriving industries have lost ground, and some have completely shut down due to the different levels of lockdown policies implemented by most of the countries around the world. Among these deeply struggling and daunting industries, both the film and tourism industries are currently two of the most damaged and annihilated ones $[73,74]$. For example, all the six Disney theme parks worldwide have indefinitely closed amid the COVID-19 outbreak, in order to contain group gathering and impose social distancing [75]. This global closedown of theme parks substantially contributes to Disney's total USD 1.4 billion loss in the first quarter of 2020 due to the COVID-19 pandemic [76]. Many Hollywood films and TV shows have halted production during the pandemic's escalation [77], while most movie theatres around the globe have been closed down. Needless to mention that the substantial reduction in global air routes and the shutdown of major cruise lines worldwide have devastated the global tourism. On the other hand, Gössling et al. argued that the COVID-19 crisis should be "seen as an opportunity to critically reconsider tourism's growth trajectory, and to question the logic of more arrivals implying greater benefits" [78] (p. 13).

Foreign tourist arrivals in Indonesia tumbled 88.95 percent year-on-year to 153,498 in September 2020, as the COVID-19 pandemic forced most countries to implement travel restrictions. The number of arrivals by air in Bali, which is the centre of the Indonesian tourism industry and where Ubud is located, slumped 100 percent to a stunning single digit eight [79]. In early September 2020, Belitung Island was just announced by the local government as a green zone that was ready to welcome tourists by applying the requisite health protocols to prevent the transmission of COVID-19-Indonesia is one of the hardest hit ASEAN countries by the coronavirus [80]. As Indonesia's neighbour, Malaysia fares comparatively better with the COVID-19 pandemic; however, when looking at the number of international tourist arrivals in the first half of 2020, it marked a $68.2 \%$ decrease compared to the same period in 2019, according to Tourism Malaysia, an agency under the Ministry of Tourism, Arts \& Culture Malaysia [81]. Although Penang's tourism industry is on the road to recovery in the second half of 2020, the local government has since modified the COVID-19 health protocols and changed strategy to revitalize domestic tourism demand, the second wave of COVID-19 surged in early October nationwide has stalled the pace of a slow recovery for Penang's tourism sector.

Following the global trend, the tourism and hospitality industry in Romania was also negatively affected by the current pandemic. The National Statistics Institute (2020) reported a decrease of $67.3 \%$ in the turnover of hotels and restaurants in the month of May 2020, while the turnover of travel agencies and tourist guides (registered under the same statistical category) registered a decline of $68.9 \%$ compared to the same month in the previous year [82].

Consequently, it is foreseeable that it should take a lengthy period of time for tourism destinations to recover in the post-COVID-19 era and regain the previous momentum gathered before the pandemic. Film-induced tourism is precisely positioned on the nexus of the two most calamitous industries-film and tourism-ravaged by the Covid-19 pandemic; however, it is worth noting that some positive, swift business model changes across the two industries have already taken place. Some production companies in Hollywood and South Korea have responded quickly to move online to release their new films directly appealing to viewers at home [83], this is why the online content provider Netflix viewership is rising amid the COVID-19 pandemic [84]. Although the six Disney theme parks around the world have been all closed, Disney has instead offered different formats of "virtual trip" such as virtual ride experiences, virtual parades and recipes through multiple online platforms [85].

Therefore, the COVID-19 calamity as a Black Swan factor does and will have a long-term, substantial impact on both the film and tourism industry in terms of business model rectification and strategic revamp in the post-COVID-19 reopening. The recovery of tourism industry, therefore, especially needs innovative and refreshing concepts and solutions to think forwardly and operate wisely, in order to turn some predictably negative or disadvantageous factors into the positive usefulness of promotional strategies. 
The creation of tourist and cultural routes and itineraries may be an appropriate way to manage sustainable flow of tourists to less recognised places and special forms of tourists; for example, literary tourism can contribute to this distributary [86]. So can film-induced tourism. The planning in this direction may be carried out by studying film-induced tourists' spatiotemporal behaviours on social media. The changes in tourist behaviours at a particular destination can be analysed via three dimensions: total tourist volumes, the structure of tourism flow networks, and the spatiotemporal patterns of tourists [15]. All the three dimensions can be observed and investigated after the COVID-19 pandemic which may be brought under control globally and the ensuing international tourist flows resume gradually.

\section{Conclusions}

A severe and perilous crisis like the COVID-19 pandemic sheds a new light on issues of both over-tourism and under-tourism, and provides an opportunity to reflect the transformative strategy to post-crisis [87]. From the policy-support and film-induced tourism development perspectives, $\mathrm{Ng}$ et al. recommended a dedicated fund set up by both DMOs and film investors [88]. If such a supportive fund may be established appropriately, it should facilitate an arduous recovery for both tourism and film industries from the tremendous declination caused by the COVID-19 pandemic. The effects of the COVID-19 pandemic on film-induced tourist destinations can be regarded from two perspectives. First, official travel restrictions, events cancellations (trade fairs, congresses, conferences, cultural and sporting events etc.), the travellers' fear of risk, generated a decline in international tourism arrivals and receipts in these destinations. Therefore, accommodation units were closed, airlines have drastically reduced their flights, cruise liners suspended travel, restaurants have restricted their activities, while leisure and entertainment activities are insignificant. While Transylvania, in Romania, may still benefit from domestic tourist flows, the other two analysed destinations, which mostly depend on international tourist arrivals, are facing even more challenging times.

Facing such a challenging time ahead, the common promotional strategy-the so called use-it-for-my-purpose tactic to attract film-induced tourist visitation-adopted by the three destinations across Southeast Europe to Southeast Asia discussed in this paper is extremely inspiring and thought-provoking. Dracula tourism in Transylvania, Romania; Ubud in Bali, Indonesia; George Town in Penang, Malaysia, all have been featured as fictional Otherness locations, although in different extents and forms - either distorted, or exoticised, or even displaced from their original identities-in most Hollywood and Western movies. The three destinations, however, all successfully turn the fictional, negative imagery and the unwanted imaginaries into positive and tangible promotional strategies. Interestingly, the three cases altogether form up a stratification of multiple stages in terms of implementing film-induced tourism strategies to promote the respective destination, spanning from the matured film-induced tourist destination Transylvania to the emerging Ubud in Bali and the sprouting George Town in Penang. The inventive, albeit differing, marketing solutions facilitate their transformation from a "fictional, imaginary" location in films to a diversified, sustainable tourist destination in reality, benefiting from their rich culture distinctions and historical heritages and then impacting on tourists' cultural demands to meet their wider expectations in a longer term. Last but not least, it is crucial for tourism policymakers and destination operators to co-operate and carry out film-induced concepts and devices elaborately, in order to promote their destinations effectively and sustainably in the game-changing post-COVID-19 era.

Although there are many travel restrictions which may keep visitors away from film-induced tourist destinations (especially those which involve long-haul transportation, such as Ubud in Bali and George Town in Penang), destination management organisations (DMOs) may approach different online marketing tools meant to keep potential visitors' interest in these locations. Such initiatives may include: posting promotional videos and teasers on social media channels, launching contests for social media users with prizes that include complete packages or limited services in the destination as well as online virtual tours in certain film-locations. Depending on the medical situation and legal 
restrictions in each destination, at a specific moment or season, DMOs may also consider applying offline marketing tools, such as organising familiarisation trips for bloggers and influencers, who may write about their own experience within different film locations in the post-COVID-19 era.

Despite its contribution to the recent literature on film-induced tourism, the present study has some limitations, which open the path for future research. First, the study is based on the comparative analysis of film-induced tourism strategies implemented in three tourist destinations (one from Europe and two from Asia). Future studies may consider comparing destinations from different continents and countries. The approach of film-induced tourism may vary throughout countries or cultures, so it is important to capture differences between them. A second limitation might be our chosen research methods. Yin, 2018 stated: "Multiple-case study designs have distinct advantages and disadvantages in comparison with single-case study designs", and he further pointed out that one goal of a multiple-case study was to build up a general explanation that fitted each individual case despite the varying details of respective cases [89]. Another limitation is given by the qualitative research method. Other researchers may consider conducting surveys among visitors or different types of stakeholders, with representative samples for each category in different countries, in order to be able to generalise the results.

Author Contributions: Conceptualization, Y.L., W.L.C., F.N. and A.N.C.; methodology, Y.L., F.N.; validation, Y.L., F.N., W.L.C. and A.N.C.; formal analysis, Y.L., F.N., W.L.C. and A.N.C.; resources, Y.L., F.N. and A.N.C.; data curation, F.N. and A.N.C.; writing-original draft preparation, Y.L. and W.L.C.; writing-review and editing, F.N. and A.N.C.; supervision, Y.L. and F.N. All authors have read and agreed to the published version of the manuscript.

Funding: This research received no external funding.

Acknowledgments: Y. Liu would like to express his sincere and heartfelt gratitude to Transilvania Fellowship Programme sponsored by Transilvania University of Brașov, Romania.

Conflicts of Interest: The authors declare no conflict of interest.

\section{References}

1. Gyimóthy, S.; Lundberg, C.; Lindström, K.; Lexhagen, M.; Larson, M. Popculture Tourism: A Research Manifesto. In Tourism Research Frontiers: Beyond the Boundaries of Knowledge; Emerald Group Publishing: Bingley, UK, 2015; Published online; pp. 13-26. [CrossRef]

2. Lee, S.; Bai, B. Influence of popular culture on special interest tourists' destination image. Tour. Manag. 2016, 52, 161-169. [CrossRef]

3. Connell, J. Film tourism-Evolution, progress and prospects. Tour. Manag. 2012, 33, 1007-1029. [CrossRef]

4. Pan, S. The role of TV commercial visuals in forming memorable and impressive destination images. J. Travel Res. 2009, 50, 171-185. [CrossRef]

5. Riley, R.; Baker, D.; Van Doren, C.S. Movie induced tourism. Ann. Tour. Res. 1998, 25, 919-935. [CrossRef]

6. Young, A.F.; Young, R. Measuring the effects of film and television on tourism to screen locations: A theoretical and empirical perspective. J. Travel Tour. Mark. 2008, 24, 195-212. [CrossRef]

7. Frost, W. Braveheart-ed Ned Kelly: Historic films, heritage tourism and destination image. Tour. Manag. 2006, 27, 247-254. [CrossRef]

8. Hudson, S.; Ritchie, J.B. Promoting destinations via film tourism: An empirical identification of supporting marketing initiatives. J. Travel Res. 2006, 44, 387-396. [CrossRef]

9. Gjorgievski, M.; Trpkova, S.M. Movie induced tourism: A new tourism phenomenon. UTMS J. Econ. 2012, 3, 97-104.

10. Mandić, A.; Petrić, L.; Pivčević, S. Film as a creative industry constituent and its impacts on tourism development: Evidence from Croatia. Tour. South East. Eur. 2017, 4, 335-348. [CrossRef]

11. Beeton, S. Understanding film-induced tourism. Tour. Anal. 2006, 11, 181-188. [CrossRef]

12. Schofield, P. Cinematographic Images of a City: Alternative Heritage Tourism in Manchester. Tour. Manag. 1996, 17, 333-400. [CrossRef]

13. Rewtrakunphaiboon, W. Film-Induced Tourism: Inventing a Vacation to a Location. 2009. Available online: http://www.bu.ac.th/knowledgecenter/epaper/jan_june2009/pdf/Walaiporn.pdf (accessed on 11 October 2019). 
14. Özdemir, G.; Adan, Ö. Film tourism triangulation of destinations. Procedia Soc. Behav. Sci. 2014, 148, 625-633. [CrossRef]

15. Du, Y.; Li, J.; Pan, B.; Zhang, Y. Lost in Thailand: A case study on the impact of a film on tourist behavior. J. Vacat. Mark. 2020, 26, 365-377. [CrossRef]

16. Busby, G.; Klug, J. Movie-induced tourism: The challenge of measurement and other issues. J. Vacat. Mark. 2001, 7, 316-332. [CrossRef]

17. Kim, H.; Richardson, S. Motion picture impacts on destination images. Ann. Tour. Res. 2003, 30, $216-237$. [CrossRef]

18. Grihault, N. Film tourism-The global picture. Travel Tour. Anal. 2003, 5, 1-22.

19. Leotta, A. Touring the Screen: Tourism and New Zealand Film Geographies; Intellect: Bristol, UK, 2011.

20. Waade, A. Nordic noir tourism and television landscapes: In the footsteps of kurt wallander and saga noren. Scandinavica 2016, 55, 41-65.

21. Croy, W.G. Planning for film tourism: Active destination image management. Tour. Hosp. Plan. Dev. 2010, 7, 21-30. [CrossRef]

22. Blanchet, C.; Fabry, N. Influence of new cinematographic and television operators on the attractivity of tourist destinations. J. Tour. Futur. 2020. [CrossRef]

23. Nieto-Ferrando, J. Tourist destination placement in fiction films: An applied research proposal. Commun. Soc. 2020, 33, 1-17. [CrossRef]

24. Skoko, B.; Miličević, K. From winnetou to game of thrones. In The Routledge Companion to Media and Tourism; Routledge: Abingdon, UK, 2020.

25. Thelen, T.; Kim, S.; Scherer, E. Film tourism impacts: A multi-stakeholder longitudinal approach. Tour. Recreat. Res. 2020, 1-16. [CrossRef]

26. Baleiro, R.; Quinteiro, S. Key Concepts in Literature and Tourism Studies; Universidade de Lisboa, Faculdade de Letras, Centro de Estudos Comparatistas: Lisbon, Portugal, 2018.

27. Larson, M.; Lundberg, C.; Lexhagen, M. Thirsting for vampire tourism: Developing pop culture destinations. J. Destin. Mark. Manag. 2013, 2, 74-84. [CrossRef]

28. Jamal, T.; Camargo, B.A. Sustainable tourism, justice and an ethic of care: Toward the just destination. J. Sustain. Tour. 2014, 22, 11-30. [CrossRef]

29. Lundberg, C.; Lindström, K.N. Sustainable management of popular culture tourism destinations: A critical evaluation of the twilight saga servicescapes. Sustainability 2020, 12, 5177. [CrossRef]

30. Wray, M.; Croy, W.G. Film tourism: Integrated strategic tourism and regional economic development planning. Tour. Anal. 2015, 20,313-326. [CrossRef]

31. O'Connor, N. A conceptual examination of the film induced tourism phenomenon in Ireland. Eur. J. Tour. Hosp. Recreat. 2011, 2, 105-125.

32. Cabeça, S.M.; Gonçalves, A.R.; Marques, J.F.; Tavares, M. Mapping intangibilities in creative tourism territories through tangible objects: A methodological approach for developing creative tourism offers. Tour. Manag. Stud. 2019, 15, 42-49. [CrossRef]

33. Richards, G. Cultural tourism: A review of recent research and trends. J. Hosp. Tour. Manag. 2018, 36, 12-21. [CrossRef]

34. Heitmann, S. Film tourism planning and development-Questioning the role of stakeholders and sustainability. Tour. Hosp. Plan. Dev. 2010, 7, 31-46. [CrossRef]

35. Mendes, R.; Vareiro, L.; Ferreira, A.R. Residents' perceptions of film-induced tourism: A Portuguese case study. Tour. Hosp. Res. 2017, 17, 424-433. [CrossRef]

36. Kim, S.; Kim, S.; Oh, M. Film tourism town and its local community. Int. J. Hosp. Tour. Adm. 2017, 18, 334-360. [CrossRef]

37. O'Connor, N.; Bolan, P. Creating a sustainable brand for Northern Ireland through film-induced tourism. Tour. Cult. Commun. 2008, 8, 147-158. [CrossRef]

38. Chin, W.L.; Liu, Y. The Film-induced tourism development in Brunei: Perspective and Potentiality. Borneo Res. J. 2018, 12, 50-70. [CrossRef]

39. Pratt, S. The borat effect: Film-induced tourism gone wrong. Tour. Econ. 2015, 21, 977-993. [CrossRef]

40. Light, D. Dracula tourism in Romania: Cultural identity and the state. Ann. Tour. Res. 2007, 34, 746-765. [CrossRef] 
41. Mrázek, J. Escaping Kakania Eastern European Travels in Colonial Southeast Asia Workshop. Call for Papers Online (January 2020). Available online: https://associazioneslavisti.com/docs/bandi-cfp/escaping-kakaniaeastern-european-travels-in-colonial-southeast-asia_12.pdf (accessed on 13 November 2020).

42. Guetterman, T.C.; Molina-Azorin, J.F.; Fetters, M.D. Virtual Special Issue on “Integration in Mixed Methods Research". J. Mix. Methods Res. 2020, 14, 430-435. [CrossRef]

43. Denzin, N.K. The Research Act: A Theoretical Introduction to Sociological Methods; McGraw Hill: New York, NY, USA, 1978; ISBN 0-07-016361-8.

44. Horwath, H.T.L. Strategic and Operational Plan for Romania's Tourism. 2011. Available online: http://turism.gov. ro/web/wp-content/uploads/2017/05/SMOP-Romania-Raport-Final.pdf (accessed on 22 June 2020).

45. Romanian National Institute of Statistics. Available online: www.insse.ro (accessed on 22 June 2020).

46. Hovi, T. The Use of History in Dracula Tourism in Romania. Folk. Electron. J. Folk. 2014, 57, 55-78. [CrossRef]

47. Candrea, A.N.; Ispas, A.; Untaru, E.; Nechita, F. Marketing the Count's way: How dracula's myth can revive romanian tourism. Bull. Transilv. Univ. Bras. Ser. V Econ. Sci. 2016, 9, 83-90.

48. Miller, E. Dracula: Sense and Nonsense; Desert Island Books: Westcliff-on-Sea, UK, 2000; ISBN 978-1874287247.

49. Light, D. When was dracula first translated into Romanian? J. Dracula Stud. 2009, 11, 2.

50. Banyai, M. Dracula's image in tourism: Western bloggers versus tour guides. Eur. J. Tour. Res. 2010, 3, 5-22.

51. Briciu, A.; Briciu, V.A. Participatory Culture and Tourist Experience: Promoting Destinations through YouTube. In Strategic Innovative Marketing and Tourism; Springer: Cham, Switzerland, 2020; pp. 425-433. [CrossRef]

52. Bergan, R. Just Don't Mention Dracula. 14 June 2007. Available online: Guardian.com (accessed on 29 April 2020).

53. Baptista, J.L.; Pocinho, M.; Nechita, F. Tourism and public policy. Bull. Transilv. Univ. Bras. Ser. V Econ. Sci. 2019, 12, 77-86. [CrossRef]

54. Nechita, F.; Demeter, R.; Briciu, V.A.; Varelas, S.; Kavoura, A. Projected destination images versus visitor-generated visual content in Brasov, Transylvania. In Strategic Innovative Marketing and Tourism; Springer: Cham, Switzerland, 2019; pp. 613-622. [CrossRef]

55. Matei, C.G. A stakeholders' Perspective on Dracula Tourism Development in Bran. Master's Thesis, Transilvania University of Brasov, Brașov, Romania, 2020.

56. Romanian Ministry of Economy, Energy and Business Environment. Available online: http://urism.gov.ro/ web/autorizare-turism/ (accessed on 22 June 2020).

57. Lupu, C.; Brochado, A.; Stoleriu, O.M. Experiencing dracula's homeland. Tour. Geogr. 2017, 19, 756-779. [CrossRef]

58. Boronnia, A.D. The Making of Negeri Laskar Pelangi (the Land of Rainbow Troops) Film Tourism as Placemaking in Indonesia. Master's Thesis, Wageningen University \& Research, Wageningen, The Netherlands, 2018. Available online: http://edepot.wur.nl/448971 (accessed on 6 October 2019).

59. Imanjaya, E.; Kusumawardhana, I. Film tourism indonesian style: The cases of laskar pelangi and eat pray love. J. Commun. Stud. 2016, 3, 9-27. [CrossRef]

60. Oktaviana, N.; Amalia, N. Gross regional domestic product forecasts using trend analysis: Case study of bangka belitung province. J. Èkon. Studi Pembang. 2018, 19, 142-151. [CrossRef]

61. Brenhouse, H. Bali's travel boom: Eat, pray, love tourism. Time, 10 August 2010

62. Mowbray, N. In search of an exotic isle: Beyond the eat, pray, love phenomenon in beautiful bali. Daily Mail, 21 June 2012

63. Chevroulet, N. Three films that helped put Asia on the production map. The Jakarta Post, 21 March 2018.

64. Hitchcock, M. Ethnicity and tourism entrepreneurship in Java and Bali. Curr. Issues Tour. 2000, 3, $204-225$. [CrossRef]

65. Blapp, M.; Mitas, O. Creative tourism in Balinese rural communities. Curr. Issues Tour. 2018, 21, $1285-1311$. [CrossRef]

66. Kim, N.; Wicks, B.E. Rethinking tourism cluster development models for global competitiveness. In Proceedings of the ICHRIE Conference, Amherst, MA, USA; 2010.

67. Chin, W.L.; Haddock-Fraser, J.; Hampton, M. Destination competitiveness: Evidence from Bali. Curr. Issues Tour. 2015, 20, 1265-1289. [CrossRef]

68. Porter, M.E. The competitive advantage of nations. Harv. Bus. Rev. 1990, 68, 73-93. 
69. Park, E. The impacts of film tourism on place change and tourist experience: A lesson from eat pray love in bali, Indonesia. In Film Tourism in Asia: Evolution, Transformation, and Trajectory; Kim, S., Reijnders, S., Eds.; Springer: Singapore, 2018; pp. 107-123.

70. Crazy Rich Asians: 5 Filming Locations in Malaysia to Visit. New Strait Times, 4 September 2018. Available online: nst.com.my (accessed on 15 October 2019).

71. Anonymous. Movie Makers Love Malaysia Nine Blockbusters, Award Winners Filmed Here. 13 May 2017. Available online: malaymail.com (accessed on 15 October 2019).

72. Yeoh, A. How Malaysia Became a Big Part of 'Crazy Rich Asians'. 21 August 2018. Available online: thestar.com.my (accessed on 15 October 2019).

73. Roxborough, S.; Brzeski, P.; McClintock, P. Global Film Industry Facing \$5 Billion Loss Amid Coronavirus Outbreak. 2 March 2020. Available online: Hollywoodreporter.com (accessed on 3 May 2020).

74. Henley, J. Guardian Correspondents. Covid-19 Throws Europe's Tourism Industry into Chaos. 2020. Available online: www.theguardian.com/world/2020/may/02/covid-19-throws-europes-tourism-industry-into-chaos (accessed on 2 May 2020).

75. Low, E. Disneyland and Walt Disney World now Indefinitely Closed Amid Coronavirus Outbreak. 27 March 2020. Available online: Variety.com (accessed on 30 April 2020).

76. Brooks, K. Disney Lost \$1.4 Billion due to Coronavirus Last Quarter. 5 May 2020. Available online: cbsnews.com (accessed on 15 May 2020).

77. Rosen, C.; Breznican, A. Here Are the TV Shows and Movies Shut down by Coronavirus. 13 March 2020. Available online: Vantityfair.com (accessed on 30 April 2020).

78. Gössling, S.; Scott, D.; Hall, M. Pandemics, tourism and global change: A rapid assessment of COVID-19. J. Sustain. Tour. 2020,1-20. [CrossRef]

79. Indonesia Tourist Arrivals 2011-2020. Available online: https://tradingeconomics.com/indonesia/touristarrivals (accessed on 13 November 2020).

80. Belitung Island Ready to Welcome Tourists: Governor. Available online: https:/en.antaranews.com/news/ 155626/belitung-island-ready-to-welcome-tourists-governor (accessed on 13 November 2020).

81. Negative Growth of $68.2 \%$ for Tourist Arrivals in the First Half of 2020. Available online: https://www. tourism.gov.my/media/view/negative-growth-of-68-2-for-tourist-arrivals-in-the-first-half-of-2020 (accessed on 13 November 2020).

82. National Statistics Institute in Romania. Turnover for Romanian Companies from the Field of Commerce and Services, Press Release nr. 189/15 July 2020. Available online: https:/insse.ro/cms/sites/default/files/ com_presa/com_pdf/turism09r20_0.pdf (accessed on 13 November 2020).

83. Sweney, M. Studios Bypass Cinemas with Lucrative Lockdown Premieres. 2 May 2020. Available online: Guardian.com (accessed on 3 May 2020).

84. Perez, L. Ted Sarandos Says “Viewing is up" for Netflix Amid Coronavirus. 22 March 2020. Available online: Hollywoodreporter.com (accessed on 30 April 2020).

85. Locke, T. Disney World Is Closed but You Can Do a Virtual Trip with Ride Experiences, Park Parades and Recipes Online-Take a Look. 11-12 April 2020. Available online: cnbc.com (accessed on 30 April 2020).

86. Quinteiro, S.; Carreira, V.; Gonçalves, A.R. Coimbra as a literary tourism destination: Landscapes of literature. Int. J. Cult. Tour. Hosp. Res. 2020, 14, 361-372. [CrossRef]

87. Ioannides, D.; Gyimóthy, S. The COVID-19 crisis as an opportunity for escaping the unsustainable global tourism path. Tour. Geogr. 2020, 1-9. [CrossRef]

88. Ng, T.M.; Chan, C.S. Investigating film-induced tourism potential: The influence of Korean TV dramas on Hong Kong young adults. Asian Geogr. 2020, 37, 53-73. [CrossRef]

89. Yin, R.K. Case Study Research and Applications: Design and Methods; Sage Publications: Thousand Oaks, CA, USA, 2018; ISBN 9781506336169.

Publisher's Note: MDPI stays neutral with regard to jurisdictional claims in published maps and institutional affiliations. 